\title{
Gendered Choices of STEM Subjects for Matriculation Are Not Driven by Prior Differences in Mathematical Achievement
}

\author{
Moshe Justman ${ }^{\#}$ and Susan J. Méndez \\ \# School of Economics and Business Administration, Ruppin Academic Center; and \\ Department of Economics, Ben Gurion University \\ ‡ Melbourne Institute of Applied Economic and Social Research, \\ The University of Melbourne
}

Corresponding author:

Susan J. Méndez

University of Melbourne, Melbourne Institute of Applied Economic and Social Research 111 Barry Street, The University of Melbourne, VIC 3010, Australia.

E-mail: susan.mendez@unimelb.edu.au 


\title{
Gendered Choices of STEM Subjects for Matriculation Are Not Driven by Prior Differences in Mathematical Achievement
}

\begin{abstract}
Women's under-representation in high-paying jobs in STEM fields (science, technology, engineering and mathematics) mirrors their earlier choices of matriculation electives: male students favour physics, information technology and advanced mathematics; female students favour life sciences. 'Pipeline' theories attribute these patterns to a male advantage in mathematics, but our longitudinal analysis, using administrative data on a full cohort of students in Victoria, Australia, shows that these patterns remain intact after conditioning on prior achievement. Female students require stronger prior signals of mathematical ability to choose male-dominated subjects, and when choosing these subjects earn higher average scores than males, suggesting a possible loss of efficiency. Previous research has shown that socioeconomic disadvantage adversely affects boys more than girls, and indeed we find less of a male advantage in physics and advanced mathematics among socially disadvantaged students. We find that students with a language background other than English choose STEM fields with greater frequency than other students, reflecting their comparative advantage, while exhibiting more markedly gendered subject choices, indicating a role for cultural factors. Finally, we find significantly less gender streaming in STEM subjects among female students in all-girl schools than in co-educational schools, but no such difference for male students.
\end{abstract}

JEL classification: I2, J24, J16

Keywords: Gender streaming, STEM, matriculation, Australia 
Increasing the participation of women in science, technology, engineering, and mathematics (STEM) fields in the workplace is a policy goal, supported by both efficiency and equity arguments, in many countries. Efficiency arguments focus on the increasingly important role of technology in economic growth and the relevance of finding the best people to work in technology related fields. Equity arguments point to lower rates of female participation in highpaying jobs, especially in engineering and information technology, as contributing substantially to the wage gap between men and women in advanced industrial economies (Groshen, 1991; Blau and Kahn, 2000; Mumford and Smith. 2007; Birch, Li and Miller, 2009). In Australia, two thirds of the gender wage gap in the starting salaries of university graduates reflects gaps between better-paid, male-dominant degree fields such as engineering and computer science, and lower-paying female-dominant fields such as nursing and teaching (Graduate Careers Australia, 2014, Table 3). ${ }^{1}$

Subject choices in tertiary education play a key role in forming these patterns. In 2013, women earned 58\% of tertiary STEM degrees in OECD countries, but less than 30\% of graduates in engineering, and less than $20 \%$ in computer science were female; and similar patterns are observed in Australia (OECD, 2013, Table A3.3). Moreover, these choices of university degree programs are shaped, in turn, by earlier subject choices in high school (Turner and Bowen, 1999; Xie and Shauman, 2003; Riegle-Crumb et al., 2012; among others). In high school, boys are typically the majority in physics and computers, and girls are the majority in life sciencesa pattern observed in Australia (Collins et al. 2000), the Netherlands (Buser et al. 2014), France (Rapoport and Thibout 2018), and in Hebrew-language schools in Israel (Ayalon 1995; Friedman-Sokuler and Justman 2016). ${ }^{2}$

The main question this paper asks is, what shapes early gendered choices of STEM subjects? To answer this question, we use administrative data from a full cohort of seventh-grade students in the state of Victoria, Australia, whom we follow from 2008 through to twelfth grade, in 2013, the last year of high school. We focus our analysis on students' STEM choices during the final two years of high school, when they are relatively independent in organising their curriculum,

\footnotetext{
${ }^{1}$ There are, of course, other factors contributing to the wage gap. Thus Cobb-Clark and Tan (2011) find that wage gaps within occupations widen over time; and Kee (2006) finds a strong glass-ceiling effect in the private sector.

${ }^{2}$ However Friedman-Sokuler and Justman (2017) find that this pattern is reversed in Israel's Arabic-language schools, and Jackson (2012) finds that in Trinidad-Tobago, girls are a majority in information technology, indicating a role for cultural factors.
} 
and aware that the subject choices they make and the scores they achieve will determine in large measure their access to tertiary education. The six principal STEM fields we study are: physics, information technology, the highest and next-highest levels of mathematics (specialist mathematics and mathematical methods), chemistry, and life sciences. Considering these fields separately reveals the heterogeneity of gender effects among STEM subjects.

We explore four factors potentially relevant to the choice of STEM subjects: prior achievement in numeracy and reading; parents' socio-economic status (SES); the role of culture, proxied by having a language background other than English; and, finally, school characteristics, in particular, the gender composition of the school. We find that, after regressing students' STEM subject choices on prior scores, parents' SES, language background and school-level variables, the gendered patterns observed in the raw data remain largely intact. Namely, physics, information technology and specialist mathematics, which open the door to well-paying careers in engineering and digital technologies, remain male-dominated, and life sciences remain female-dominated. We expand on these four factors in the following paragraphs.

First, noting that STEM subjects are mathematically intensive, many have suggested that the under-representation of women in these subjects is driven by a prior male advantage in mathematics. ${ }^{3}$ We find that boys do indeed have a significant advantage in mathematics in grades seven and nine, as measured by Australia’s National Assessment Program-Literacy and Numeracy (NAPLAN), while girls have a significant advantage in reading. However, while prior test scores are a significant predictor of STEM subject choices, they account for only a small fraction of the gender difference in subject choice. ${ }^{4}$ Previous studies attribute gender differences in educational choices to gender differences in risk aversion and competitiveness (Gneezy, Leonard and List, 2009; Niederle and Vesterlund, 2010; Booth and Nolen, 2012a, 2012b; Booth, Cardona-Sosac and Nolen, 2014), and, similarly, to girls under-estimating their

\footnotetext{
${ }^{3}$ More generally, evidence of an average male advantage is mixed and depends on age, cultural factors and type of test (Fryer and Levitt, 2010; Ceci et al., 2014; Guiso et al., 2008; Marks, 2008; Bedard and Cho, 2010; ElseQuest et al., 2010; Kane and Mertz, 2012; Bharadwaj et al., 2012, Nollenberger et al., 2016). Additionally, there is stronger evidence that greater variability in male scores makes for a male majority at higher (and lower) levels of achievement (Hedges and Nowell, 1995; Hyde et al., 2008; Ellison and Swanson, 2010; Pope and Sydnor, 2010). Finally, a male comparative advantage in mathematics is observed almost everywhere, driven by the substantial female advantage in language skills (Goldin et al., 2006; Fryer and Levitt, 2010; Wang et al., 2013).

${ }^{4}$ Previous research shows that NAPLAN scores accurately predict subsequent performance in final-year exams, suggesting they reliably indicate relevant mathematical ability (Houng and Justman, 2014).
} 
science skills when choosing their educational and career paths (Rapoport and Thibout, 2018). ${ }^{5}$ Supporting this literature, our findings suggest that female students require stronger prior signals of mathematical ability to choose physics, information technology or specialist mathematics, arguably reflecting greater caution on their part. This seemingly greater caution results in female students outperforming their male counterparts not only in these subjects but in all STEM subjects. ${ }^{6}$ This is important, because it could lead to a loss of productivity, if the infra-marginal male student specializing in, say, physics, is not as good at physics as the extramarginal female student choosing not to specialize in physics.

Next, measuring SES through parents' education and occupation, we find that socio-economic disadvantage is generally associated with a reduced likelihood of choosing to specialize in physics and specialist mathematics, and also that this negative association is stronger for boys than for girls, as Goldin et al. (2006) found. Consequently, relative gender gaps in the choice of these subjects are more prevalent at low SES levels while absolute gaps increase with SES. Third, cross-country variation in gender streaming in education highlights the role of culture in constructing gender roles (Nollenberger et al., 2016). In our Australian cohort from the state of Victoria, this is evident in the more pronounced gendered choice patterns we observe among students with a language background other than English. Furthermore, these students choose STEM subjects with greater frequency than students for whom English is their main language, presumably reflecting their comparative advantage in subjects that require numeracy skills rather than language skills.

Finally, comparing mixed schools to single-sex schools we find significantly less gender streaming in single-sex schools. Female students in single-sex schools are significantly more likely than those in mixed schools to specialize in physics, advanced mathematics and chemistry, and less likely to specialize in biology, whereas male students in co-educational and single-sex schools make similar choices. ${ }^{7}$ These findings are at variance with Billger's (2009) conclusion that in the United States, "coeducational public schools yield the least segregated college major choices"; and with Jackson’s (2012) finding that girls in single-sex schools in

\footnotetext{
${ }^{5}$ See, also, OECD (2015) for an overview of research on gender differences in attitudes to risk and competition. Additionally, other studies suggest that student choices are affected by teachers' gender biases (Lavy and Sand, 2015); and by the differential impact of institutional design on boys and girls (Joensen and Nielsen, 2015).

${ }^{6}$ Female average scores in these subjects are higher than male averages by 0.11 to 0.30 of a standard deviation.

${ }^{7}$ This suggests that girls have a stronger incentive to attend single-sex schools than boys, and indeed in our cohort $23 \%$ of girls and $16 \%$ of boys attended single-sex schools in seventh grade.
} 
Trinidad-Tobago choose fewer science subjects for matriculation than girls in co-educational schools.

The present analysis is most closely related to two longitudinal studies which look at gender differences in the choice of STEM matriculation electives in Israel and which control for middle-school achievement in Hebrew-language schools (Friedman-Sokuler and Justman, 2016). Although, a priori, it is not clear that we should expect to find similar patterns in distinct education systems, the matriculation choice patterns observed in Israel's Hebrew-language schools are similar to the patterns described here. The main difference is that, compared with boys, girls in Israel have a slight average advantage in eighth-grade standardized mathematics tests, so it is less surprising that conditioning subject choice on prior scores leaves the gender gaps observed in Israel largely intact. Interestingly, Friedman-Sokuler and Justman’s (2017) analysis of students' subject choices in Israel's Arabic-language schools finds that they exhibit less gender bias, though they serve a more traditional population with more restrictive gender norms. In these schools, female students choose to matriculate in physics and computer science as frequently as male students.

Less directly related are a number of longitudinal, survey-based studies that follow large samples of high-school graduates through to college. These studies find similar gendered streaming in the choice of STEM college majors after conditioning on prior achievement (Turner and Bowen, 1999; Xie and Shauman, 2003; Riegle-Crumb and King, 2010; RiegleCrumb et al., 2012). The differences between our findings and these-we find that prior achievement explains less of the observed gender gaps, and find a more limited role for comparative advantage ${ }^{8}$ — may stem partly from the different stages of education we study, and partly from methodological differences. We contribute to the literature by taking a full cohort of seventh-grade students as our population framework, hence avoiding selection bias and minimizing sample attrition inherent in survey-based studies that exclude students who do not reach tertiary education, as boys have higher attrition rates in high school. In addition, conditioning tertiary decisions on high-school performance that was itself shaped by gender streaming diminishes the estimated gender-specific propensity to choose among these

\footnotetext{
${ }^{8}$ We find a small effect for specialist mathematics but not for other subjects.
} 
subjects. ${ }^{9}$ Our data allow us to condition subject choice on seventh and ninth-grade scores, which predate specialization in STEM subjects.

The structure of the paper is as follows. In section 2, we briefly describe the Australian education system. Section 3 presents the data: the basic attributes of the student population; their performance on NAPLAN numeracy and reading tests in grades seven and nine; their choice of STEM subjects in the final years of high school; and their performance in these subjects. Section 4 presents our estimation strategy, section 5 presents our findings, and section 6 concludes.

\section{The Australian education system}

Australia's school system is untracked, and prepares all students for higher-level academic study. There is a mandatory requirement to complete tenth grade (when students are around 16 years old). In grades three, five, seven, and nine, students are assessed in numeracy, reading, writing, grammar and spelling, through standardized tests, under the National Assessment Program - Literacy and Numeracy (NAPLAN). School years in Australia begin in February and coincide with calendar years; NAPLAN tests are administered in May.

After finishing compulsory education in grade ten, students can go on to grades eleven and twelve and sit for exams towards an upper-secondary school certificate-in Victoria, this is the Victorian Certificate of Education (VCE). ${ }^{10}$ Subject scores on VCE exams are scaled, aggregated and harmonized with counterpart scores in other states and territories, and are used to determine a student's Australian Tertiary Admission Rank (ATAR), which ranks each student within the full cohort of Australian students in that year. ${ }^{11}$ Admissions to competitive university programs are determined by ATAR cut-off values and specific degree program prerequisites. ${ }^{12}$

\footnotetext{
${ }^{9}$ See Altonji (1993), Arcidiacono (2004), Altonji, Blom and Meghir (2012) and Zafar (2013), among others, on high-school subject choices as investment decisions that anticipate college choices.

${ }^{10}$ Alternatively, students can continue on to post-secondary vocational education and training (VET) courses. See Polidano et al. (2015) for a discussion of the VET system.

11 The lowest ATAR value assigned to a student is 30.00 and the highest is 99.95. An ATAR of 50 places one at the median of the full cohort, just under the $29^{\text {th }}$ percentile of students with an ATAR.

${ }^{12}$ For example, in 2015, the Bachelor of Biomedicine at The University of Melbourne required an ATAR of 98.85 and VCE units 3 and 4 in English/ESL creative writing, chemistry, and mathematical methods or specialist mathematics. The University of Queensland's Bachelor of Engineering program required an ATAR of 89 and VCE units 3 and 4 in English, mathematical methods, and either physics or chemistry. Some courses of study require other specialized criteria, such as portfolios for art courses or interviews for medical studies.
} 
ATAR values are determined by the sum of a scaled score in one advanced level mandatory English subject and scaled scores in the student's three best other subjects, plus $10 \%$ of the student's scaled score in at most two additional subjects.

Students in Australia can choose between fully-funded government schools and fee-paying non-government schools-Catholic or independent-which receive some financial support from the government. In Australia overall, just under two-thirds of all students attend government schools, a fifth attend Catholic schools, and the rest attend independent schools. Non-government enrolment increases with grade level and with socio-economic status. In Victoria in 2013, 43\% of secondary school students attended non-government schools (ABS, Schools, Australia, 2017). Most schools, and almost all government schools, in Australia are co-educational. In our sample, $23 \%$ of girls and $16 \%$ of boys attended single-sex schools.

\section{$3 \quad$ Data}

The data we use was provided by the Victoria Department of Education and Training (DET). The Victorian Curriculum and Assessment Authority (VCAA), which delivered the VCE assessments, also collected unit record administrative data from NAPLAN, matched it to VCE records and provided the data to DET. We follow the full 2008 cohort of seventh-grade students in Victoria through to 2013, when they reach twelfth grade. There were 66,686 seventh-grade students in 2008, of whom 51.2\% were male. From these we omit: 3,744 students aged 13 or over in May 2008 (66\% of them male); 1,076 students for whom we lack both seventh-grade and ninth-grade NAPLAN scores (62\% male); and 3,395 students for whom we lack both ninthgrade NAPLAN scores and VCE completion (52.9\% male). The remaining 58,471 students, of whom $50 \%$ are male, are our seventh-grade study cohort, which serves as the main sample for our analysis.

Table 1 presents descriptive statistics that compare the full cohort and the study cohort. The two are generally similar, except for slightly greater attrition among male students, among older students and among Aborigine and Torres Island students. Almost a quarter of the study cohort has a language background other than English (LBOTE), and less than 1\% are Aboriginal or Torres Strait Islanders (ATSI). We divided the student population into four socio-economic 
categories, determined by parents' occupation and education. ${ }^{13}$ The four categories are roughly equal in size. Attrition was greater in the lowest of these categories.

Table 1. Descriptive statistics, seventh-grade cohort

\begin{tabular}{|c|c|c|c|c|}
\hline & \multicolumn{2}{|c|}{ Full cohort } & \multicolumn{2}{|c|}{ Study cohort } \\
\hline & Mean & Std. Dev. & Mean & Std. Dev. \\
\hline Female & 0.488 & 0.500 & 0.500 & 0.500 \\
\hline Age & 11.875 & 0.479 & 11.809 & 0.393 \\
\hline Language background other than English & 0.245 & 0.430 & 0.241 & 0.427 \\
\hline Aborigine and Torres Strait Islander & 0.012 & 0.108 & 0.008 & 0.089 \\
\hline SES 1 (lowest) & 0.249 & 0.432 & 0.230 & 0.421 \\
\hline SES 2 & 0.241 & 0.427 & 0.244 & 0.430 \\
\hline SES 3 & 0.276 & 0.447 & 0.280 & 0.449 \\
\hline SES 4 (highest) & 0.235 & 0.424 & 0.245 & 0.430 \\
\hline Completed VCE & 0.605 & 0.489 & 0.666 & 0.472 \\
\hline Completed VCE, female & 0.665 & 0.472 & 0.720 & 0.449 \\
\hline Number of observations & \multicolumn{2}{|c|}{66,686} & \multicolumn{2}{|c|}{58,471} \\
\hline
\end{tabular}

Note. Unit record data provided by the Victorian Department of Education and Training. SES: Socioeconomic status.

VCAA linked the merged seventh-grade and ninth-grade NAPLAN data to the 2013 VCE files, allowing us to compute VCE completion rates. Treating students not in our 2013 VCE file as having dropped out of school after tenth grade leaves us with $66.6 \%$ of our seventh-grade study cohort completing their VCE in 2013. This is 3.4 percentage points lower than the national target share of $70 \%$. We attribute this difference to students moving to other states or migrating overseas, repeating or skipping a grade, or choosing to sit for the equivalent International Baccalaureate Diploma instead of the VCE. Further analysis of these effects, in Appendix B, indicates that this attrition should not significantly bias our results. ${ }^{14}$

\footnotetext{
${ }^{13}$ See Appendix A for definitions and a detailed comparison of the full cohort and the study cohort.

${ }^{14}$ Attrition due to estimated migration rates from Victoria-which should be gender neutral—roughly closes the gap between the observed and the national levels of completion. Further attrition is due to students repeating or skipping a grade, and completing their VCE earlier or later than 2013, or taking the alternative International Baccalaureate Diploma, smaller effects that raise the true completion rate for our study sample slightly above the national rate of $70 \%$. This is to be expected, as Victoria's student population is academically stronger than the Australian average, and our study sample is academically stronger than the full sample.
} 


\subsection{Education achievement measures}

\subsubsection{Selection of STEM subjects in upper-secondary school}

Students choose their VCE subjects with a view to maximising their ATAR score given their abilities and motivation, while meeting specific degree program prerequisites, preparing themselves for a future course of study, and addressing their personal inclinations. In keeping with our focus on high school matriculation as a gateway to jobs in engineering and digital technologies, we restrict our attention to six principal STEM fields: physics; information technology (comprising software development, information technology applications, and systems engineering); specialist mathematics (the highest level of mathematics); mathematical methods (the next highest level); chemistry; and life sciences (comprising biology and environmental science). In harmonizing scores across subjects, five of the STEM subjects we consider were scaled up. These are, in descending order of the scaling parameter: specialist mathematics, mathematical methods, chemistry, physics, and life sciences. Information technology was scaled down.

Table 2. VCE STEM choices and scores, by gender

\begin{tabular}{|c|c|c|c|c|c|c|c|}
\hline & \multicolumn{3}{|c|}{ Female } & \multicolumn{3}{|c|}{ Male } & \multirow{2}{*}{ Female - Male } \\
\hline & Mean & Std. Dev. & $\mathrm{N}$ & Mean & Std. Dev. & $\mathrm{N}$ & \\
\hline Subject choice frequencies & & & & & & & Share difference ${ }^{a}$ \\
\hline Physics & 0.028 & 0.165 & 29,244 & 0.145 & 0.352 & 29,227 & -0.117 \\
\hline Information technology & 0.011 & 0.105 & 29,244 & 0.095 & 0.293 & 29,227 & -0.084 \\
\hline Specialist mathematics & 0.026 & 0.158 & 29,244 & 0.065 & 0.247 & 29,227 & -0.039 \\
\hline Mathematical methods & 0.141 & 0.348 & 29,244 & 0.178 & 0.382 & 29,227 & -0.036 \\
\hline Chemistry & 0.124 & 0.330 & 29,244 & 0.129 & 0.335 & 29,227 & -0.005 \\
\hline Life sciences & 0.221 & 0.415 & 29,244 & 0.122 & 0.328 & 29,227 & 0.099 \\
\hline Standardized VCE test score & & & & & & & Score difference ${ }^{b}$ \\
\hline Physics & 0.174 & 0.973 & 824 & -0.034 & 1.002 & 4,231 & 0.208 \\
\hline Information technology & 0.125 & 0.985 & 323 & -0.032 & 1.011 & 2,782 & 0.157 \\
\hline Specialist mathematics & 0.129 & 0.929 & 748 & -0.051 & 1.023 & 1,900 & 0.180 \\
\hline Mathematical methods & 0.167 & 0.957 & 4,134 & -0.133 & 1.014 & 5,188 & 0.301 \\
\hline Chemistry & 0.067 & 0.975 & 3,634 & -0.065 & 1.019 & 3,777 & 0.132 \\
\hline Life sciences & 0.039 & 0.997 & 6,469 & -0.068 & 1.005 & 3,576 & 0.107 \\
\hline
\end{tabular}

Note. ${ }^{\text {a }}$ Share difference is the unconditional gender gap in subject choice, i.e., the share of female students choosing a given STEM subject minus the share of male students. ${ }^{b}$ Score difference is the gender gap in standardized test scores, i.e., the female average test score minus the male average.

In our study cohort $72.1 \%$ of female students and $61.1 \%$ of male students completed their VCE in 2013. Among students with an ATAR, female students have an average rank of 64.5 while male students have an average rank two percentage points lower, 62.5 . 
The top panel of Table 2 shows the share of male and female students in the seventh-grade cohort choosing each STEM subject, and the difference between the female and male shares, for each of our STEM categories. Male and female students tend to choose differently among STEM subjects. Male students choose physics, information technology and specialist mathematics more frequently; female students choose life sciences more frequently; and a similar share of male and female students choose chemistry and mathematical methods. The subjects are ordered in ascending order of the gender difference in shares, female share minus male share. The bottom panel of Table 2 presents average standardized scores in each subject, by gender. Female students substantially outperform male students in both male-dominated and female-dominated subjects.

\subsubsection{Prior scores: NAPLAN achievement in grades seven and nine}

We restrict our study cohort to include only students with at least one NAPLAN score. Of these 58,471 students, 48,078 have a complete set of four NAPLAN scores and 10,393 have at least one but fewer than four scores. We standardize all scores to have a mean of zero and a standard deviation of one and, for these 10,393 students, impute the missing standardized scores as follows. Where a ninth-grade score is missing and we have the corresponding seventh-grade subject score we set the ninth-grade score equal to the seventh-grade score $(6,542$ cases in numeracy, 6,435 in reading), and vice versa (1,443 cases in numeracy, 1,516 in reading). Where we have a reading score in at least one year but no numeracy score in either year we set the numeracy score equal to the reading score in each year (240 cases), and vice versa (284 cases).

Table 3 presents standardized test score means in grades seven and nine, for numeracy and reading, by gender, with and without imputed scores. In seventh grade boys score higher than girls in numeracy, by 0.27 of a standard deviation on average, while scoring 0.11 of a standard deviation lower than girls in reading. In ninth grade, boys' advantage in numeracy declines slightly to 0.25 of a standard deviation while girls' advantage in reading increases to 0.20 of a standard deviation. Comparing test score averages with and without imputed scores, we find that imputation slightly lowers average scores, as students with missing scores are generally weaker than average, but as male and female students are similarly affected, the gender differences in the right-most column are almost unchanged by the imputation procedure. ${ }^{15}$

\footnotetext{
${ }^{15}$ To verify that our regression results are not driven by these imputations, we re-estimated our principal regressions separately for the 48,078 students with all four tests scores. The results, presented in Appendix Table D, are very similar to those obtained from the study cohort of 58,471 students, presented in Appendix Table C.
} 
Table 3. NAPLAN standardized scores, by gender

\begin{tabular}{|c|c|c|c|c|c|c|c|}
\hline & \multicolumn{3}{|c|}{ Female } & \multicolumn{3}{|c|}{ Male } & \multirow{2}{*}{$\begin{array}{c}\text { Female } \\
\text { advantage }^{a}\end{array}$} \\
\hline & Mean & Std. Dev. & $\mathrm{N}$ & Mean & Std. Dev. & $\mathrm{N}$ & \\
\hline \multicolumn{8}{|l|}{ Seventh grade numeracy } \\
\hline without imputed values & -0.138 & 0.938 & 28,463 & 0.138 & 1.041 & 28,325 & -0.276 \\
\hline with imputed values & -0.148 & 0.938 & 29,244 & 0.119 & 1.044 & 29,227 & -0.267 \\
\hline \multicolumn{8}{|l|}{ Seventh grade reading } \\
\hline without imputed values & 0.052 & 0.973 & 28,395 & -0.052 & 1.024 & 28,276 & 0.105 \\
\hline with imputed values & 0.041 & 0.977 & 29,244 & -0.070 & 1.028 & 29,227 & 0.111 \\
\hline \multicolumn{8}{|l|}{ Ninth grade numeracy } \\
\hline without imputed values & -0.126 & 0.931 & 25,810 & 0.126 & 1.050 & 25,875 & -0.252 \\
\hline with imputed values & -0.146 & 0.933 & 29,244 & 0.102 & 1.060 & 29,227 & -0.249 \\
\hline \multicolumn{8}{|l|}{ Ninth grade reading } \\
\hline without imputed values & 0.100 & 0.971 & 25,874 & -0.100 & 1.019 & 25,878 & 0.199 \\
\hline with imputed values & 0.079 & 0.979 & 29,244 & -0.117 & 1.026 & 29,227 & 0.196 \\
\hline
\end{tabular}

Note. NAPLAN test scores are standardized with a mean of zero and a standard deviation of one. Of our study sample of 58,417 students, 10,393 have incomplete NAPLAN test score data. We imputed missing scores as follows. Within each domain, if a ninth-grade score was missing we replaced it by the seventh-grade score, if available, and vice-versa.For students for whom we have at least one reading score but no numeracy scores, we set the numeracy score equal to the reading score in each year, and vice versa. Roughly $7 \%$ of our NAPLAN scores are imputed. ${ }^{a}$ Female advantage is the mean female score minus the mean male score.

In all four tests, male scores exhibit greater variability than female scores, as indicated by their larger standard deviations. Male students are over-represented at the high end of the distribution in both grades seven and nine, as indicated by the male-to-female ratio exceeding one for the three highest deciles, shown in Figure $1 .^{16}$

\footnotetext{
${ }^{16}$ In other countries, the greater variability of male outcomes leads also to a male majority at the lower end of the distribution but this is not the case here (see note 3 above, for references to other studies).
} 
Figure 1. Male to female ratio, by NAPLAN numeracy score decile

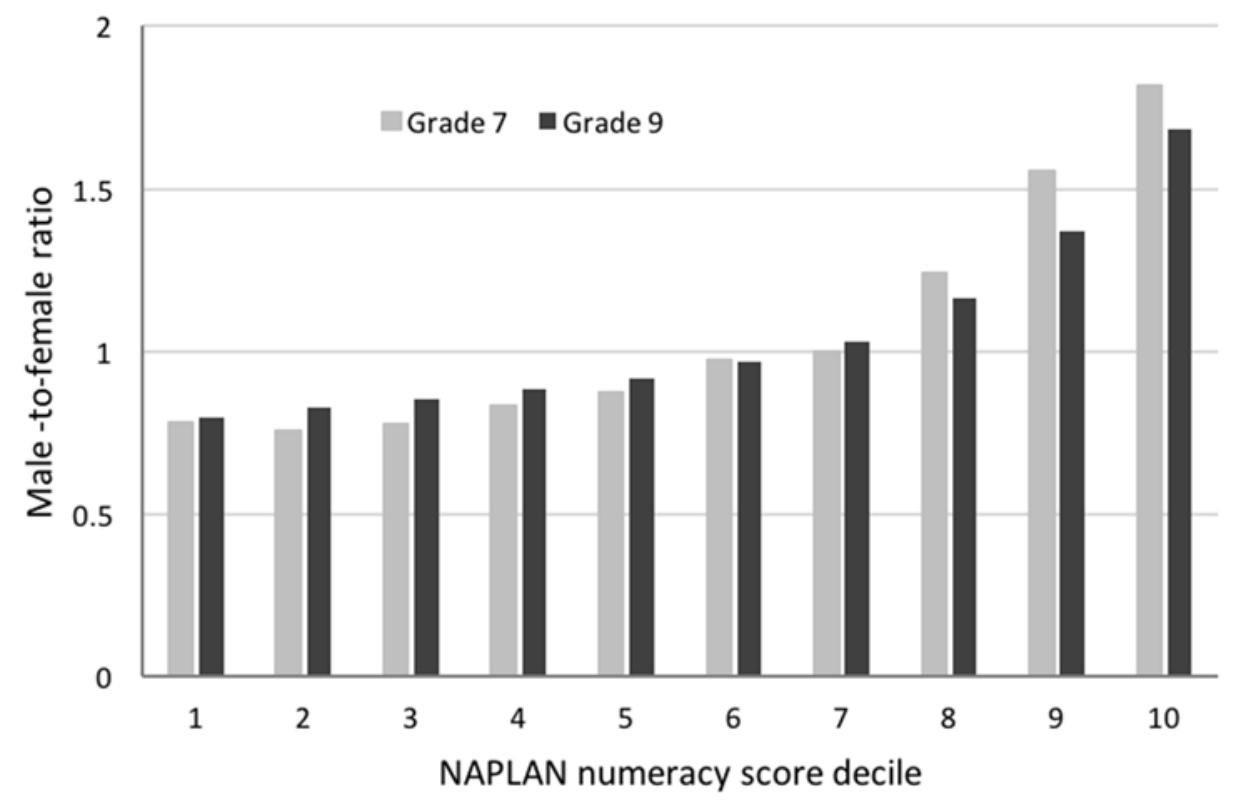

\subsection{School-level characteristics}

We also explore the association of subject choice with six school-level variables: government affiliation; the school's median, standardized seventh-grade numeracy score among all its students, among its female students and among its male students (three variables); ${ }^{17}$ the school's median SES category; and the share of female students in the school. Means and standard deviations calculated over the study cohort population of 58,471 students are presented in Table 4.

To further explore differences between school types, we present selected descriptive statistics for co-educational and single-sex schools, by gender, in Table 5. We classify students' school types-government or non-government, co-educational or single-sex-according to their school affiliation in seventh grade. Of the 606 schools in our seventh-grade study cohort, 496 are co-educational, 65 are all-girls schools and 45 are all-boys schools; the large majority of single-sex schools are non-government schools. Students in single-sex schools are more likely to be high SES; and boys and girls in single-sex schools have much higher NAPLAN scores on all four tests. In our study cohort, 759 students switched from a co-educational school in

\footnotetext{
${ }^{17}$ For single-sex schools we set the missing gender's median standardized numeracy score equal to zero.
} 
seventh grade to a single-sex school in ninth grade (411 boys, 348 girls); and 574 moved in the opposite direction, from a single-sex to a co-educational school (230 boys, 344 girls).

Table 4. School level variables, descriptive statistics

\begin{tabular}{lcc}
\hline & Mean & Std.Dev \\
\hline Government school indicator & 0.563 & 0.496 \\
Median standardized seventh grade numeracy, all & -0.095 & 0.458 \\
Median standardized seventh grade numeracy, female & -0.242 & 0.412 \\
Median standardized seventh grade numeracy, male & 0.013 & 0.454 \\
Median SES category & 2.533 & 0.774 \\
Share of female students & 0.500 & 0.230 \\
\hline
\end{tabular}

Note. Descriptive statistics based on school attended in grade 7. Number of observations: 58,471

Panel B in Table 5 shows the raw differences in choice frequencies between co-educational and single-sex schools. We observe substantial differences in the subject choices of female students between single-sex and co-educational schools, with all-girl schools exhibiting less pronounced gendered choice patterns. Thus, female students in single-sex schools choose life sciences five times as often as physics while those in co-educational schools choose life sciences ten times as often as physics. Among male students, the corresponding difference between co-educational and all-boy schools is much smaller. 
Table 5. Coeducational and single-sex schools, by gender

\begin{tabular}{|c|c|c|c|c|c|c|c|c|}
\hline & \multicolumn{4}{|c|}{ Female } & \multicolumn{4}{|c|}{ Male } \\
\hline & \multicolumn{2}{|c|}{ Co-educational } & \multicolumn{2}{|c|}{ Single-sex } & \multicolumn{2}{|c|}{ Co-educational } & \multicolumn{2}{|c|}{ Single-sex } \\
\hline & Mean & Std. Dev. & Mean & Std. Dev. & Mean & Std. Dev. & Mean & Std. Dev. \\
\hline \multicolumn{9}{|l|}{ Panel A } \\
\hline Language background other than English & 0.225 & 0.418 & 0.279 & 0.449 & 0.242 & 0.428 & 0.253 & 0.435 \\
\hline \multicolumn{9}{|l|}{ Socio-economic status frequencies } \\
\hline SES 1 (lowest) & 0.269 & 0.443 & 0.106 & 0.308 & 0.257 & 0.437 & 0.080 & 0.272 \\
\hline SES 2 & 0.274 & 0.446 & 0.162 & 0.368 & 0.259 & 0.438 & 0.144 & 0.351 \\
\hline SES 3 & 0.261 & 0.439 & 0.337 & 0.473 & 0.263 & 0.440 & 0.382 & 0.486 \\
\hline SES 4 (highest) & 0.197 & 0.398 & 0.395 & 0.489 & 0.221 & 0.415 & 0.393 & 0.489 \\
\hline \multicolumn{9}{|l|}{ Standardized NAPLAN scores } \\
\hline Seventh grade numeracy & -0.251 & 0.899 & 0.192 & 0.985 & 0.051 & 1.028 & 0.477 & 1.051 \\
\hline Seventh grade reading & -0.055 & 0.960 & 0.362 & 0.966 & -0.135 & 1.019 & 0.279 & 1.005 \\
\hline Ninth grade numeracy & -0.252 & 0.898 & 0.204 & 0.961 & 0.019 & 1.030 & 0.546 & 1.103 \\
\hline Ninth grade reading & -0.027 & 0.966 & 0.434 & 0.934 & -0.193 & 1.021 & 0.286 & 0.955 \\
\hline \multicolumn{9}{|l|}{ Panel B } \\
\hline \multicolumn{9}{|l|}{ Subject choice frequencies } \\
\hline Physics & 0.021 & 0.144 & 0.052 & 0.222 & 0.139 & 0.346 & 0.174 & 0.379 \\
\hline Information technology & 0.011 & 0.106 & 0.010 & 0.098 & 0.095 & 0.293 & 0.098 & 0.298 \\
\hline Specialist mathematics & 0.019 & 0.137 & 0.047 & 0.213 & 0.060 & 0.237 & 0.093 & 0.290 \\
\hline Mathematical methods & 0.114 & 0.318 & 0.232 & 0.422 & 0.160 & 0.367 & 0.268 & 0.443 \\
\hline Chemistry & 0.098 & 0.297 & 0.213 & 0.410 & 0.117 & 0.321 & 0.195 & 0.396 \\
\hline Life sciences & 0.211 & 0.408 & 0.254 & 0.436 & 0.114 & 0.318 & 0.168 & 0.374 \\
\hline Life sciences to physics ratio & 10.048 & & 4.885 & & 0.820 & & 0.966 & \\
\hline Number of students per school & 71.932 & 35.681 & 138.760 & 54.485 & 79.225 & 38.751 & 167.731 & 57.563 \\
\hline Number of schools ${ }^{a}$ & \multirow{2}{*}{\multicolumn{2}{|c|}{22,499}} & \multicolumn{2}{|c|}{65} & & & \multicolumn{2}{|c|}{45} \\
\hline Number of students & & & \multicolumn{2}{|c|}{6,745} & \multicolumn{2}{|c|}{24,599} & \multicolumn{2}{|c|}{4,628} \\
\hline
\end{tabular}

Note. Descriptive statistics by school type and gender based on school attended in grade $7 .{ }^{a}$ Number of co-educational schools 496 


\section{$4 \quad$ Empirical strategy}

To analyse the relationship between subject choice and gender, controlling for the multiple factors discussed above, we estimate separate equations for each STEM subject, starting with the following linear probability model:

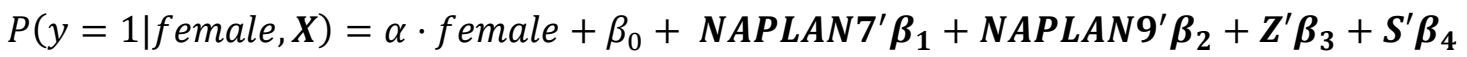

For each STEM subject, $y$ is a binary variable that takes the value one if the student chooses that subject for VCE. The probability of choosing subject $y$ is a linear function of female, a dummy indicating gender, and a vector of control variables $(\boldsymbol{X})$. These variables are: the vector of numeracy and reading scores in seventh-grade NAPLAN; the vector of numeracy and reading scores in ninth-grade NAPLAN; a vector of personal characteristics $\boldsymbol{Z}$, which includes language background other than English and dummies for the SES categories; and a vector of school characteristics $\boldsymbol{S}$, which includes the six variables in Table 4: a government school dummy; the median standardized numeracy score in grade seven for all students, for female students and for male students; the median SES category; and the share of female students in the school.

To discuss in more detail the role of prior scores, SES and language background, we estimate each of the six equations separately for female and male students:

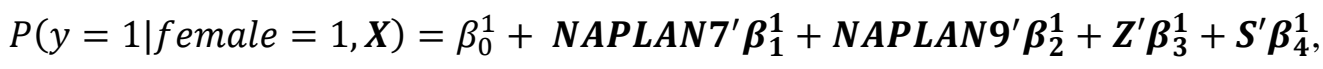

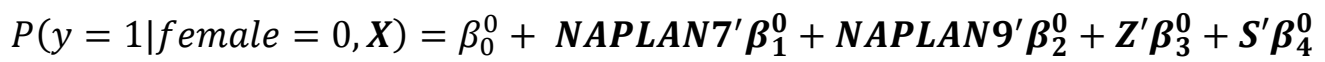

Finally, we explore the influence of different school types by separately estimating linear regression models for female students in single-sex schools, female students in co-educational schools, male students in single-sex schools, and male students in co-educational schools. These models replace the vector of school characteristics $(\boldsymbol{S})$ with a full set of school fixedeffects $(\boldsymbol{\tau})$. The estimation equation is:

$$
P(y=1 \mid \text { female, school, } \boldsymbol{X})=\beta_{0}^{f s}+\boldsymbol{N A P L A N 7 ^ { \prime }} \boldsymbol{\beta}_{1}^{f s}+\boldsymbol{N A P L A N 9 ^ { \prime }} \boldsymbol{\beta}_{2}^{f s}+Z^{\prime} \boldsymbol{\beta}_{3}^{f s}+\boldsymbol{\tau}(3)
$$

where female can be one $(f=1)$ or zero $(f=0)$ and school can be single-sex $(s=1)$ or co-educational $(s=0)$. 


\section{$5 \quad$ Results}

\subsection{Gender differences in subject choice}

In this section, we first provide graphical evidence of the relationship between seventh-grade NAPLAN numeracy ranks and the gendered patterns we observe in the choice of VCE STEM subjects. We then present our regression results.

Figure 2 is a graphic representation of gender differences in the propensity to choose STEM subjects, conditioned only on prior numeracy ranks. It shows the share of male and female students in the seventh-grade cohort subsequently choosing each of the STEM fields, at each percentile in the distribution of seventh grade NAPLAN numeracy scores. ${ }^{18}$ For all subjects the share of both male and female students choosing that subject increases with prior achievement in numeracy, but they increase at different rates, reflecting gender differences in the propensity to choose each subject conditional on prior numeracy scores. Physics, information technology and specialist mathematics are male-dominated subjects at almost all points of the distribution of prior achievement, while life sciences is a female-dominated subject at each point of the score distribution. Figure 2 also shows that, conditional on prior numeracy scores, female students have a slightly greater propensity to choose chemistry—a pattern not revealed in the raw differences.

\footnotetext{
${ }^{18}$ The graphs are smoothed by local quadratic regressions using the STATA LOWESS procedure.
} 
Figure 2. Propensity to choose STEM subjects by gender and grade 7 numeracy rank
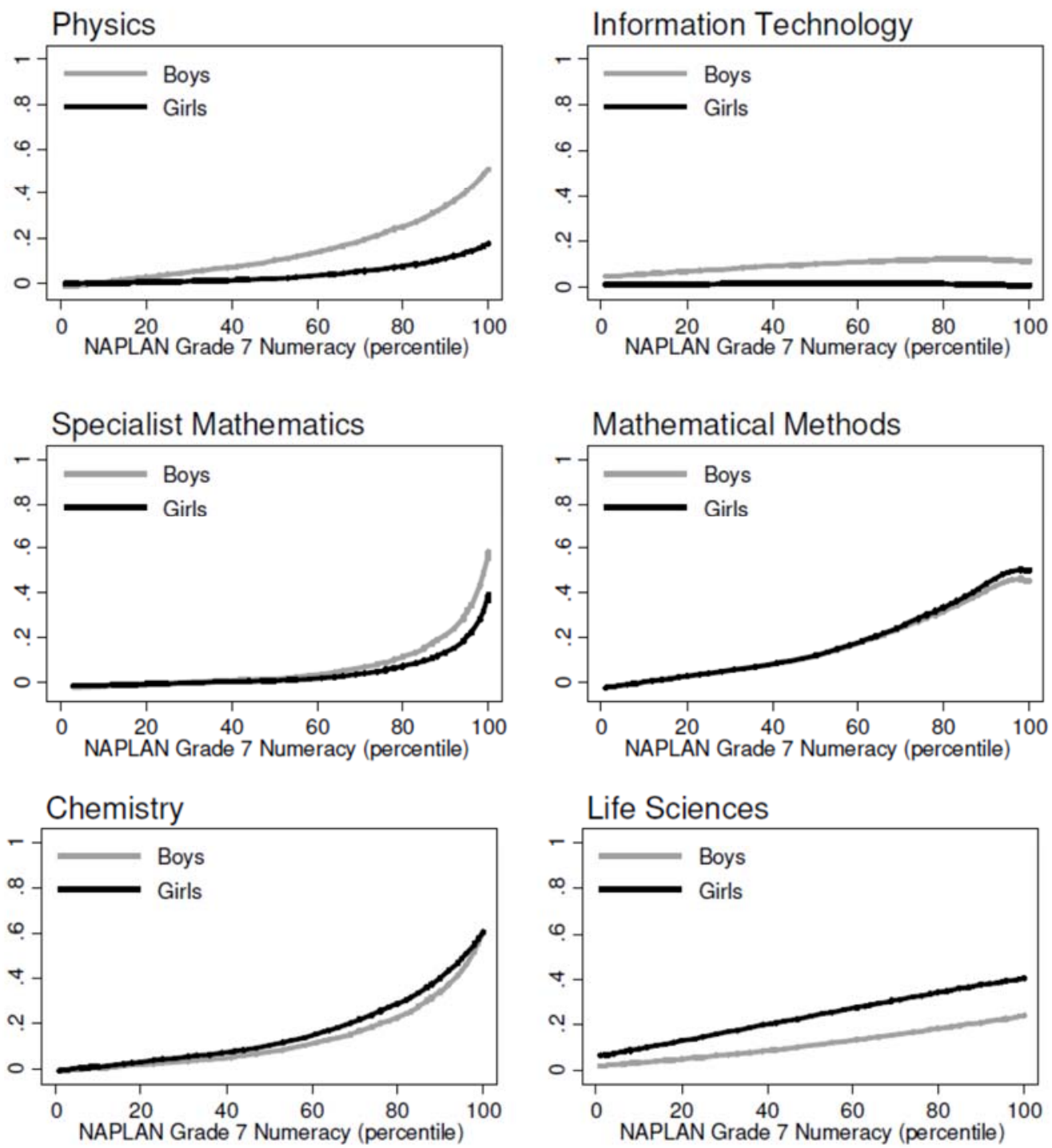

To determine if these gendered patterns remain after controlling for other factors we estimate the linear probability models specified in equation (1) adding our control variables successively. The first four columns of Table 6 present our estimates of $\alpha$, the female coefficient, for four specifications. ${ }^{19}$ In column (1) we regress students' binary choice of each subject only on gender. In this regression, $\alpha$ represents the raw gender difference identical to

19 The coefficients and standard errors of all control variables from equation (1) are presented in Table C in the Appendix. We also estimated probit equations for each subject with the same set of variables, and obtained very similar results. We prefer the OLS specification because marginal effects are derived directly from the coefficients. 
the right-most column in the top panel of Table 2. We then add seventh- and ninth-grade numeracy and reading scores, in column (2); socio-economic category dummies and language background in column (3); and the school-level variables in column (4). Column (5) shows the proportion of the gender differences that are not attributed to endowments effects, but to differences in coefficients, from a Blinder-Oaxaca decomposition based on the full set of control variables used in column (4). ${ }^{20}$

Overall, these results highlight the persistence of the principal gendered patterns of STEM subject choice observed in the raw data, even after the addition of an extensive set of controls. The large male advantage in physics and information technology remains, though in physics it is reduced by 2.4 percentage points, and the large female advantage in life sciences is stable. The modest male advantage in specialist mathematics and mathematical methods is substantially reduced, though remaining significant; and there appears a modest but significant female advantage in chemistry where the raw male advantage was not statistically significant. ${ }^{21}$

These results show that observed patterns of gender streaming in the choice of STEM electives for matriculation remain mostly intact after controlling for differences in prior achievement, socio-economic status, language background and school characteristics. In the following subsections, we look more closely at the different impact of the control variables on the choice of STEM subjects, taking as our point of departure the separate estimates of subject choice by gender that underlie equations (2A) and (2B). Table 7 presents estimated coefficients for selected control variables; the full set of coefficients with standard errors are provided in Appendix E.

\footnotetext{
${ }^{20}$ We follow Jann (2008) for the Blinder-Oaxaca decomposition for linear regression models.

${ }^{21}$ We conducted similar analyses for non-STEM subjects, with the same controls, and found that female students choose legal studies, psychology, history, literature, philosophy, art, geography, sociology, foreign languages, and music and theatre more frequently than male students, while male students choose economics and physical education more often.
} 


\begin{tabular}{|c|c|c|c|c|c|}
\hline & (1) & (2) & (3) & (4) & $\begin{array}{l}\text { Blinder- } \\
\text { Oaxaca }\end{array}$ \\
\hline Physics & $\begin{array}{l}-0.117^{* * *} \\
(0.004)\end{array}$ & $\begin{array}{l}-0.092^{* * *} \\
(0.003)\end{array}$ & $\begin{array}{l}-0.093^{* * *} \\
(0.003)\end{array}$ & $\begin{array}{l}-0.091 * * * \\
(0.003)\end{array}$ & $\begin{array}{l}-0.093^{* * *} \\
(0.006)\end{array}$ \\
\hline $\begin{array}{l}\text { Information } \\
\text { Technology }\end{array}$ & $\begin{array}{l}-0.084^{* * *} \\
(0.003)\end{array}$ & $\begin{array}{l}-0.084^{* * *} \\
(0.003)\end{array}$ & $\begin{array}{l}-0.085^{* * *} \\
(0.003)\end{array}$ & $\begin{array}{l}-0.083^{* * *} \\
(0.004)\end{array}$ & $\begin{array}{l}-0.086^{* * *} \\
(0.006)\end{array}$ \\
\hline $\begin{array}{l}\text { Specialist } \\
\text { Mathematics }\end{array}$ & $\begin{array}{l}-0.039 * * * \\
(0.003)\end{array}$ & $\begin{array}{l}-0.013^{* * *} \\
(0.002)\end{array}$ & $\begin{array}{l}-0.014^{* * *} \\
(0.002)\end{array}$ & $\begin{array}{l}-0.013 * * * \\
(0.002)\end{array}$ & $\begin{array}{l}-0.015^{* * *} \\
(0.004)\end{array}$ \\
\hline $\begin{array}{l}\text { Mathematical } \\
\text { Methods }\end{array}$ & $\begin{array}{l}-0.036^{* * *} \\
(0.006)\end{array}$ & $\begin{array}{l}-0.001 \\
(0.004)\end{array}$ & $\begin{array}{l}-0.003 \\
(0.004)\end{array}$ & $\begin{array}{l}-0.009 * * * \\
(0.003)\end{array}$ & $\begin{array}{l}-0.006 \\
(0.006)\end{array}$ \\
\hline Chemistry & $\begin{array}{l}-0.005 \\
(0.006)\end{array}$ & $\begin{array}{l}0.030^{* * *} \\
(0.004)\end{array}$ & $\begin{array}{l}0.027^{* * *} \\
(0.004)\end{array}$ & $\begin{array}{l}0.018^{* * *} \\
(0.003)\end{array}$ & $\begin{array}{l}0.022^{* * *} \\
(0.005)\end{array}$ \\
\hline Life Sciences & $\begin{array}{l}0.099 * * * \\
(0.005)\end{array}$ & $\begin{array}{l}0.103 * * * \\
(0.004)\end{array}$ & $\begin{array}{l}0.102 * * * \\
(0.004)\end{array}$ & $\begin{array}{l}0.103 * * * \\
(0.004)\end{array}$ & $\begin{array}{l}0.100 * * * \\
(0.006)\end{array}$ \\
\hline Prior NAPLAN scores & no & yes & yes & yes & yes \\
\hline SES, LBOTE & no & no & yes & yes & yes \\
\hline School level variables & no & no & no & yes & yes \\
\hline
\end{tabular}

Note. $N=58,471$. Each entry in columns (1) to (4) reports the coefficient of female, in regressions derived from equation (1), with control variables added successively as indicated in the bottom three rows. For example: The probability of choosing physics as a VCE subject is 11.7 percentage points lower for a female than for a male student, without controls (column 1); and 9.1 percentage points lower when including the full set of controls (column 4). Column (5) shows the proportion of gender differences attributed to differences in coefficients, from a Blinder-Oaxaca decomposition based on the full set of controls. Standard errors clustered by seventh-grade school are reported in parentheses. ${ }^{* \star \star},{ }^{\star *},{ }^{*}$ indicate statistical significance at the $1 \%, 5 \%$ and $10 \%$ levels, respectively.

\subsection{Prior achievement: NAPLAN grade-nine numeracy scores}

Figure 2 above illustrates that subject choice responses to the signal of achievement in numeracy, in seventh-grade scores, differ by gender. To further highlight and quantify these gender differences the first two columns of Table 7 present the coefficients of standardized NAPLAN numeracy scores in grade nine from separate regressions by gender as defined in equations (2A) and (2B). Numeracy scores in ninth-grade NAPLAN are highly significant for female and male students across all STEM subjects, however there are differences in the magnitude of the coefficients. For comparable male and female students, an increase of one standard deviation in prior numeracy scores is associated with an increase of 2.9 percentage points in the probability of a female student choosing physics, and a 9.0 percentage point 
increase for a male student. Similarly, for specialist mathematics the male response is twice the magnitude of the female response. However, in life sciences the difference is reversed, with the female response much greater than the male response. These findings are consistent with an extensive experimental literature highlighting gender differences in attitudes towards risk and competitiveness, which lead male and female students with similar prior scores to make different choices. ${ }^{22}$ We discuss the impact of prior scores in further detail below, when we compare differences between co-educational and single-sex schools for male and female students.

Table 7. Coefficient results for selected control variables of linear probability model estimated by gender

\begin{tabular}{|c|c|c|c|c|c|c|c|c|}
\hline \multirow[t]{3}{*}{ Coefficient of control variable: } & \multicolumn{2}{|c|}{ NAPLAN Numeracy Grade 9} & \multicolumn{2}{|c|}{ LBOTE } & \multicolumn{2}{|c|}{ SES 4} & \multicolumn{2}{|c|}{ Share of female students } \\
\hline & Female & Male & Female & Male & Female & Male & Female & Male \\
\hline & (1) & (2) & (3) & (4) & (5) & (6) & (7) & (8) \\
\hline \multirow[t]{2}{*}{ Physics } & $0.029 * * *$ & $0.090 * * *$ & $0.019 * * *$ & $0.072 * * *$ & 0.003 & $0.043 * * *$ & $0.031^{* * *}$ & 0.025 \\
\hline & $(0.003)$ & $(0.004)$ & $(0.003)$ & $(0.006)$ & $(0.003)$ & $(0.007)$ & $(0.008)$ & $(0.024)$ \\
\hline \multirow[t]{2}{*}{ Information technology } & $0.002 *$ & $0.008^{* *}$ & $0.008^{* * *}$ & $0.033 * * *$ & 0.002 & 0.000 & -0.011 & -0.007 \\
\hline & $(0.001)$ & $(0.004)$ & $(0.002)$ & $(0.006)$ & $(0.002)$ & $(0.006)$ & $(0.008)$ & $(0.023)$ \\
\hline \multirow[t]{2}{*}{ Specialist mathematics } & $0.040 * * *$ & $0.080 * * *$ & $0.037^{* * *}$ & $0.056 * * *$ & -0.003 & $0.011 * *$ & $0.013^{*}$ & 0.020 \\
\hline & $(0.003)$ & $(0.004)$ & $(0.003)$ & $(0.005)$ & $(0.003)$ & $(0.005)$ & $(0.008)$ & $(0.015)$ \\
\hline \multirow{2}{*}{ Mathematical methods } & $0.103^{* * *}$ & $0.090 * * *$ & $0.116 * * *$ & $0.090 * * *$ & $0.021 * * *$ & $0.057^{* * *}$ & $0.078 * * *$ & 0.002 \\
\hline & $(0.005)$ & $(0.005)$ & $(0.007)$ & $(0.007)$ & $(0.007)$ & $(0.007)$ & $(0.019)$ & $(0.027)$ \\
\hline \multirow[t]{2}{*}{ Chemistry } & $0.097^{* * *}$ & $0.091 * * *$ & $0.118^{* * *}$ & $0.092 * * *$ & $0.021 * * *$ & $0.040 * * *$ & $0.063 * * *$ & 0.011 \\
\hline & $(0.005)$ & $(0.005)$ & $(0.007)$ & $(0.007)$ & $(0.006)$ & $(0.006)$ & $(0.017)$ & $(0.026)$ \\
\hline \multirow[t]{2}{*}{ Life sciences } & $0.077^{* * *}$ & $0.031 * * *$ & $0.064 * * *$ & $0.040 * * *$ & $0.074 * * *$ & $0.047^{* * *}$ & $-0.055^{* *}$ & -0.010 \\
\hline & $(0.005)$ & $(0.004)$ & $(0.008)$ & $(0.006)$ & $(0.008)$ & $(0.006)$ & $(0.026)$ & $(0.024)$ \\
\hline Number of students & 29,244 & 29,227 & 29,244 & 29,227 & 29,244 & 29,227 & 29,244 & 29,227 \\
\hline
\end{tabular}

Note. Coefficients of selected control variables, from separate linear probability models of subject choice by gender as specified in equation (2A) and (2B). Each regression includes controls for prior scores, SES categories, language background and school-level variables. Standard errors clustered by seventh-grade school are reported in parentheses. ${ }^{* * *},{ }^{* *}, *$ indicate statistical significance at the $1 \%, 5 \%$ and $10 \%$ levels, respectively. See Appendix E for full regression results.

\subsection{Language background other than English}

Almost a quarter of our seventh-grade cohort report having a language background other than English (LBOTE). We find that both male and female LBOTE students have higher STEM choice frequencies in all subjects, as indicated by the uniformly significant positive coefficients of LBOTE in both sets of equations (columns (3) and (4) in Table 7). This lends support to the comparative advantage hypothesis, assuming that students with a language background other than English are at a disadvantage in language-intensive subjects, beyond differences in ability

\footnotetext{
${ }^{22}$ See, among others, Gneezy, Leonard and List (2009), Niederle and Vesterlund (2010), Booth and Nolen (2012a, 2012b), Booth, Cardona-Sosac and Nolen (2014). The coefficients of ninth-grade reading scores are much smaller, and most are not statistically significant (Appendix F). Significant but small negative coefficients in three of the four regressions for specialist mathematics indicate a limited role for comparative advantage. In three of the four regressions in mathematical methods and life sciences, the reading coefficients are significant and positive.
} 
reflected in NAPLAN literacy scores. We also find evidence of more pronounced gender streaming in the subject choices of LBOTE students: LBOTE status is associated with an increase in the choice of male-dominated subjects (e.g., physics) for males, more so than for female students; and with an increase in the choice of female dominated subjects (e.g., life sciences) by females, more so than for male students. This suggests that cultural factors play a role in shaping these gendered choices. ${ }^{23}$

Additionally, we note the extremely low participation rate of Indigenous students in STEM subjects. Of 498 Aboriginal students in our cohort, only 44 chose any STEM elective, and only seven students-all of them male-chose either physics, information technology or specialist mathematics.

\subsection{Socio-economic status}

Column (5) and (6) in Table 7 present the estimated coefficients from equation (2A) and (2B) of an indicator for the highest SES category (SES 4), where the omitted category is the lowest SES category (SES 1). The coefficients are larger for male than for female students across all subjects except information technology, where neither the male nor the female coefficient is statistically significant, and life sciences. Socio-economic background makes more of a difference for male students than for female students, with regard to choosing these four subject categories. This is consistent with Goldin et al. (2006) and others, who find that social disadvantage adversely affects male education outcomes more than female outcomes.

\subsection{School characteristics}

School level variables generally had little effect on our estimates of gender gaps in subject choice, with the important exception of the school's gender composition. After controlling for median numeracy grades, SES and gender composition, there is little difference in gender gaps between government and non-government schools, except that male students in government schools choose information technology less frequently, by 4 percentage points. The median school SES has no significant effect on any of the subjects, for male or female students, nor do we see a systematic effect of median NAPLAN scores on gender differences in subject choice.

\footnotetext{
${ }^{23}$ LBOTE students come from a wide range of countries, and the estimated average effect hides differences between immigrant groups. In Victoria, languages other than English spoken at home most commonly are: Mandarin, Italian, Greek, Vietnamese and Arabic. We do not have student-level information on country of origin.
} 
The estimated coefficient values of the share of female students in the school are reported in column (7) and (8) in Table 7. They indicate that in schools with a larger share of females, female students choose physics, mathematical methods and chemistry significantly more frequently, and life sciences significantly less frequently, whereas for male students the gender composition of the school has no significant effect on subject choice, for any subject.

This difference between male and female students is highlighted when we compare coeducational schools to single-sex schools, by estimating the model defined in equation (3) separately by gender and school type. Table 8 presents the coefficient of standardized ninthgrade test scores on STEM subject choice from these four equations, with full results in Appendix F.

Table 8. Coefficients of ninth-grade numeracy scores, by gender and school type

\begin{tabular}{|c|c|c|c|c|}
\hline & \multicolumn{2}{|c|}{ Female } & \multicolumn{2}{|c|}{ Male } \\
\hline & Co-educational & Single-sex & Co-educational & Single-sex \\
\hline \multirow[t]{2}{*}{ Physics } & $0.022 * * *$ & $0.052 * * *$ & $0.091 * * *$ & $0.092 * * *$ \\
\hline & $(0.003)$ & $(0.006)$ & $(0.005)$ & $(0.012)$ \\
\hline \multirow[t]{2}{*}{ Information technology } & 0.001 & $0.006 * * *$ & $0.013^{* * *}$ & -0.007 \\
\hline & $(0.001)$ & $(0.002)$ & $(0.004)$ & $(0.007)$ \\
\hline \multirow[t]{2}{*}{ Specialist mathematics } & $0.032 * * *$ & $0.067 * * *$ & $0.079 * * *$ & $0.094 * * *$ \\
\hline & $(0.003)$ & $(0.008)$ & $(0.004)$ & $(0.010)$ \\
\hline \multirow[t]{2}{*}{ Mathematical methods } & $0.099 * * *$ & $0.116 * * *$ & $0.089 * * *$ & $0.082 * * *$ \\
\hline & $(0.005)$ & $(0.012)$ & $(0.005)$ & $(0.013)$ \\
\hline \multirow[t]{2}{*}{ Chemistry } & $0.089 * * *$ & $0.120 * * *$ & $0.088^{* * *}$ & $0.111^{* * *}$ \\
\hline & $(0.005)$ & $(0.011)$ & $(0.005)$ & (0.009) \\
\hline \multirow[t]{2}{*}{ Life sciences } & $0.076 * * *$ & $0.081^{* * *}$ & $0.031 * * *$ & $0.035 * * *$ \\
\hline & $(0.006)$ & $(0.011)$ & $(0.005)$ & $(0.012)$ \\
\hline Number of students & 22,499 & 6,745 & 24,599 & 4,628 \\
\hline
\end{tabular}

Note. Coefficients of the variable Numeracy Grade 9, from separate OLS subject choice regressions estimated by gender and school type as specified in equation (3). Each regression includes controls for prior scores, SES categories, language background and school fixed effects. Standard errors clustered by seventh-grade school are reported in parentheses. ${ }^{* * *}$, $* *, *$ indicate statistical significance at the $1 \%, 5 \%$ and $10 \%$ levels, respectively. See Appendix $\mathrm{F}$ for full regression results. 
Numeracy scores are highly significant and predictive of STEM choices regardless of gender and school type, except for information technology. The coefficients for physics and specialist mathematics are much larger for male than for female students, consistent with the patterns observed throughout the paper. However, these gendered patterns are less pronounced for female students in single-sex schools than in co-educational schools. For male students, the differences between single-sex and co-educational schools are much smaller.

\section{Conclusions}

Previous studies have shown that women's under-representation in high-paying jobs in engineering and information technology, which contributes substantially to the gender wage gap, reflects earlier patterns in tertiary education. In this paper we show that gender streaming into STEM related subjects in the Australian state of Victoria is already apparent already in senior secondary school, in students' choice of STEM subjects for matriculation, and we consider the contribution of various factors to explaining these patterns.

We follow a full cohort of seventh-grade students in Victoria in 2008 through to the twelfth grade in 2013, and find a large male majority among students choosing to matriculate in physics, information technology and specialist mathematics, and a large female majority among those choosing life sciences. Our longitudinal data allows us to control for prior achievement on national tests in seventh and ninth grades in numeracy and reading, and directly test the widely maintained hypothesis that the gendered choices of matriculation subjects we observe are driven by gender differences in mathematical ability. We find that these patterns of subject choice remain essentially intact after controlling for prior scores, leading us to reject this hypothesis.

Male and female students react differently to the signals of scholastic ability inherent in prior test scores. Where male students who do well on prior tests choose matriculation electives in physics, information technology and specialist mathematics, female students with high prior scores prefer life sciences. These effects are less pronounced in all-girl schools, where the gendered patterns we observe are weaker than for female students in co-educational schools. We find no such difference between male students in all-male and co-educational schools. Male and female students also react differently to socio-economic disadvantage. Specific propensities to choose STEM subjects decline with socio-economic disadvantage for all students, but the decline is more pronounced for male students, supporting previous findings 
on the greater adverse effect of socio-economic disadvantage on boys than on girls. Finally, students with a non-English language background choose all STEM subjects more frequently than other students, male and female, holding prior scores and SES constant. This is consistent with the hypothesis that comparative advantage in mathematics affects subject choice, but may also reflect cultural factors. In addition, the gendered patterns of choice observed in the general population are more pronounced among these students, which again may reflect cultural factors.

Overall, we find that the roots of women's under-representation in high-paying jobs in engineering and information technology are already apparent in the different choices male and female students make in secondary school. These pertain to specific STEM subject choices rather than to STEM in general and, for the most part, do not reflect prior differences in mathematical achievement or other relevant scholastic skills. This suggests that their choices are mostly shaped by social norms, socio-economic background, cultural factors and perceived economic incentives. Finally, we note that female students who choose to matriculate in physics or information technology earn higher grades on average than male students who choose these subjects, suggesting that there may also be efficiency gains to be had from attenuating gender differences in the choice of STEM subjects for VCE matriculation.

\section{Acknowledgments}

This research was commissioned by the Victorian Department of Education and Training (DET). It uses unit record data from Australia’s National Assessment Program—Literacy and Numeracy (NAPLAN) from an administrative data collection created by the Victorian Curriculum and Assessment Authority (VCAA), which delivered the Victorian Certificate of Education (VCE) assessments, matched student data and provided the data to DET. The findings and views reported in this paper are those of the authors and should not be attributed to DET or any other branch of the Victorian or Australian Commonwealth government. We thank for their comments Deborah Cobb-Clark, Brendan Houng, Sonja Kassenboehmer, Gary Marks, Julie Moschion, Cain Polidano, David Ribar, Chris Ryan, and seminar participants at the University of Melbourne, Swinburne University, Universidad del Rosario, the $19^{\text {th }}$ Australian Labour Econometrics Workshop, and the 2016 Latin American Meetings of the Econometric Society. 


\section{References}

ABS, Schools, Australia (2017).

http://www.abs.gov.au/AUSSTATS/abs@.nsf/Lookup/4221.0Main+Features12017?OpenD ocument

Altonji, JG, 1993. The demand for and return to education when education outcomes are uncertain. Journal of Labor Economics, 11: 48-83.

Altonji, JG, Blom, E and Meghir, C, 2012. Heterogeneity in human capital investments: High school curriculum, college major, and careers. WP 17985, NBER.

Arcidiacono, P 2004. Ability sorting and the returns to college major. Journal of Econometrics, 121: 343-375.

Ayalon, H, 1995. Math as a gatekeeper: Ethnic and gender inequality in course taking of the sciences in Israel. American Journal of Education, 104: 34-56.

Bedard, K and Cho, I, 2010. Early gender test score gaps across OECD countries. Economics of Education Review, 29: 348-363.

Bharadwaj, P, Giorgi, GD, Hansen, D and Neilson, C, 2012. The gender gap in mathematics: Evidence from low- and middle-income countries. WP 18464. Cambridge, MA: NBER.

Billger, SM, 2009. On reconstructing school segregation: The efficacy and equity of singlesex schooling. Economics of Education Review 28(3):393-402.

Birch, ER, Li, I, and Miller, PW, 2009. The influence of institution attended and field of study on graduates’ starting salaries. Australian Economic Review, 42 (1): 42-63.

Blau, FD, Kahn, LM, 2000. Gender differences in pay. The Journal of Economic Perspectives 14, 75-99. Booth, A, 2009. Gender and competition. Labour Economics, 16: 599-606.

Booth, A, Cardona-Sosac, L, and Nolen, P, 2014. Gender differences in risk aversion: Do single-sex environments affect their development? Journal of Economic Behavior and Organization 99: 126-154.

Booth, A and Nolen, P, 2012a. Choosing to compete: How different are girls and boys? Journal of Economic Behavior \& Organization, 81(2): 542-555.

Booth, A and Nolen, P, 2012b. Gender differences in risk behaviour: does nurture matter? The Economic Journal, 122(558): F56-F78.

Buser, T, Niederle, M and Oosterbeek, H, 2014. Gender, competitiveness, and career choices. The Quarterly Journal of Economics, 129: 1409-1447.

Ceci, SJ, Ginther, DK, Kahn, S and Williams, WM, 2014. Women in academic science: A changing landscape. Psychological Science in the Public Interest, 15(3): 75-141.

Cobb-Clark, D and Tan, M, 2011. Noncognitive skills, occupational attainment, and relative wages. Labour Economics, 18: 1-13.

Collins, C, Kenway, J and McLeod, J, 2000. Factors influencing the educational performance of males and females in school and their initial destinations after leaving school. Deakin University and the University of South Australia.

Ellison, G and Swanson, A, 2010. The gender gap in secondary school mathematics at high achievement levels: Evidence from the American mathematics competitions, Journal of Economic Perspectives, 24: 109-28. 
Else-Quest, NM, Hyde, JS and Linn, MC, 2010. Cross-national patterns of gender differences in mathematics: A meta-analysis. Psychological Bulletin, 136: 103-127.

Friedman-Sokuler, N and Justman, M, 2016. Gender streaming and prior achievement in high school science and mathematics. Economics of Education Review 53:230-253..

Friedman-Sokuler, N and Justman, M, 2017. Gender Equality and Women in STEM: The Case of Arab Women in Israel. Working paper, Bar-Ilan University.

Fryer, RG and Levitt, SD, 2010. An empirical analysis of the gender gap in mathematics. American Economic Journal: Applied Economics, 2: 210-240.

Gneezy, U, Leonard, KL and List, JA, 2009. Gender differences in competition: Evidence from a matrilineal and a patriarchal society. Econometrica, 77: 1637-1664.

Goldin, C, Katz, LF and Kuziemko, I, 2006. The homecoming of American college women: The reversal of the college gender gap. WP12139. Cambridge, MA: NBER.

Graduate Careers Australia, 2014. An analysis of the gender wage gap in the Australian graduate labour market, 2013.

Groshen, E, 1991. The structure of the female/male wage differential. Journal of Population Economics 26:457-472.

Guiso, L, Monte, F, Sapienza, P and Zingales, L, 2008. Culture, gender, and math. Science, 320: 1164-1165.

Hedges, LV and Nowell, A, 1995. Sex differences in mental test scores, variability, and numbers of high-scoring individuals. Science, 269: 41-45.

Houng, B and Justman, M, 2014. NAPLAN Scores as Predictors of Access to Higher Education in Victoria. Melbourne Institute Working Paper 22/14. Melbourne University.

Hyde, JS, Lindberg, SM, Linn, MC, Ellis, AB and Williams, CC, 2008. Gender similarities characterize math performance. Science, 321: 494-495.

Jackson, CK, 2012. Single-sex schools, student achievement, and course selection: Evidence from rule-based student assignments in Trinidad and Tobago. Journal of Public Economics 96(1):173-187.

Jann, B, 2008. The Blinder-Oaxaca decomposition for linear regression models. The Stata Journal, 8(4): 453-479.

Joensen, JS and Nielsen, HS, 2015. Mathematics and gender: Heterogeneity in causes and consequences. The Economic Journal, forthcoming.

Kane, JM and Mertz, JE, 2012. Debunking myths about gender and mathematics performance. Notices of the American Mathematical Society, 59: 10-21.

Kee, HJ, 2006. Glass ceiling or sticky floor? Exploring the Australian gender pay gap. The Economic Record, 82: 408-427.

Lavy, V and Sand, E, 2015. On the origins of gender human capital gaps: Short and long term consequences of teachers' stereotypical biases. WP 20909. Cambridge, MA: NBER.

Marks, GN, 2008. Accounting for the gender gaps in student performance in reading and mathematics: evidence from 31 countries. Oxford Review of Education, 34(1): 89-109.

Mumford, K, Smith, PN, 2007. The gender earnings gap in Britain: Including the workplace. The Manchester School 75(6):653-672. 
Niederle, M and Vesterlund, L (2010) Explaining the gender gap in math test scores: The role of competition, The Journal of Economic Perspectives, 24: 129-144.

Nollenberger N, Rodríguez-Planas N and Sevilla A, 2016. The math gender gap: The role of culture. American Economic Review, 106(5): 257-261.

OECD (2013), Education at a Glance 2013: OECD Indicators, OECD Publishing, Paris. DOI: http://dx.doi.org/10.1787/eag-2013-en

OECD (2015), The ABC of gender equality in education: Aptitude, behaviour, confidence, PISA. OECD Publishing. DOI: http://dx.doi.org/10.1787/9789264229945-en

Polidano, C, Tabasso, D and Tseng YP, 2015. A second chance at education for early school leavers. Education Economics, 23(3):358-75.

Pope, DG and Sydnor, JR, 2010. Geographic variation in the gender differences in test scores, The Journal of Economic Perspectives, 24: 95-108.

Rapoport, B and Thibout, C. 2018. Why do boys and girls make different educational choices? The influence of expected earnings and test scores. Economics of Education Review, 62: 205-229.

Riegle-Crumb, C and King, B, 2010. Questioning a white male advantage in STEM: Examining disparities in college major by gender and race/ethnicity. Educational Researcher, 39: 656-664.

Riegle-Crumb, C, King, B, Grodsky, E and Muller, C, 2012. The more things change, the more they stay the same? Prior achievement fails to explain gender inequality in entry into stem college majors over time. American Educational Research Journal, 49: 1048-1073.

Turner, SE and Bowen, WG, 1999. Choice of major: The changing (unchanging) gender gap. Industrial and Labor Relations Review, 52: 289-313.

Wang, M-T, Eccles, JS and Kenny, S, 2013). Not lack of ability but more choice: Individual and gender differences in choice of careers in science, technology, engineering, and mathematics, Psychological Science, 24: 770-775.

Xie, Y and Shauman, KA, 2003. Women in science: Career processes and outcomes. Cambridge, MA: Harvard University Press.

Zafar, B, 2013. College major choice and the gender gap. Journal of Human Resources, 48: 545-595. 


\section{Appendix A. Definition of socio-economic categories}

We define five joint categories of parental education from their separate education levels in our data, listed in Table A2, as follows:

1. Least educated: neither parent above grade 10

2. Partial high school: at least one parent grade 11 or certificate

3. Both missing: both not stated or unknown

4. Full high school: at least one parent grade 12 or diploma

5. Higher education: at least one parent with bachelor degree or more.

Similarly, we define joint categories of parental occupation, from their separate occupation types in our data, listed in Table A2, as follows:

1. Both unemployed, or father's occupation unknown, and the mother is neither a manager nor a professional.

2. One parent not working and the other is neither a manager nor a professional.

3. Both employed, but neither of them is a manager or a professional.

4. Both unknown.

5. Father or mother is a manager or a professional.

Then we define four levels of family socio-economic status (SES) from these two taxonomies of parental education and occupation, as set out in Table A1.

Table A1. Definition of family SES levels

\begin{tabular}{|c|c|c|c|c|c|}
\hline \multirow{2}{*}{$\begin{array}{l}\text { Family } \\
\text { education }\end{array}$} & \multicolumn{2}{|l|}{ Family occupation } \\
\cline { 2 - 6 } & $\mathbf{1}$ & $\mathbf{2}$ & $\mathbf{3}$ & $\mathbf{4}$ & $\mathbf{5}$ \\
\hline $\mathbf{1}$ & 1 & 1 & 2 & 2 & 2 \\
\hline $\mathbf{2}$ & 1 & 1 & 2 & 2 & 3 \\
\hline $\mathbf{3}$ & 1 & 1 & 3 & 3 & 4 \\
\hline $\mathbf{4}$ & 1 & 2 & 3 & 3 & 4 \\
\hline $\mathbf{5}$ & 2 & 3 & 4 & 4 & 4 \\
\hline
\end{tabular}


Table A2 presents descriptive statistics for parent's education and occupation for the full cohort and the study cohort.

Table A2. Descriptive statistics: Parents' occupation and education

\begin{tabular}{|c|c|c|c|c|}
\hline \multirow{2}{*}{ Basis: Seventh grade students } & \multicolumn{2}{|c|}{ Full cohort } & \multicolumn{2}{|c|}{ Study cohort } \\
\hline & Mean & Std. Dev. & Mean & Std. Dev. \\
\hline \multicolumn{5}{|l|}{ Father's occupation } \\
\hline Unknown & 0.272 & 0.445 & 0.258 & 0.437 \\
\hline Unemployed & 0.080 & 0.271 & 0.075 & 0.263 \\
\hline Manual labourer & 0.167 & 0.373 & 0.166 & 0.372 \\
\hline Tradesmen/women & 0.177 & 0.382 & 0.182 & 0.386 \\
\hline Manager or associate professional & 0.178 & 0.383 & 0.186 & 0.389 \\
\hline Senior manager or professional & 0.126 & 0.332 & 0.133 & 0.339 \\
\hline \multicolumn{5}{|l|}{ Mother's occupation } \\
\hline Unknown & 0.133 & 0.340 & 0.130 & 0.336 \\
\hline Unemployed & 0.232 & 0.422 & 0.216 & 0.412 \\
\hline Manual labourer & 0.178 & 0.383 & 0.179 & 0.383 \\
\hline Tradesmen/women & 0.188 & 0.390 & 0.195 & 0.396 \\
\hline Manager or associate professional & 0.156 & 0.363 & 0.161 & 0.367 \\
\hline Senior manager or professional & 0.113 & 0.317 & 0.118 & 0.323 \\
\hline \multicolumn{5}{|l|}{ Father's education } \\
\hline Unknown & 0.274 & 0.446 & 0.257 & 0.437 \\
\hline Grade 9 or less & 0.054 & 0.226 & 0.051 & 0.220 \\
\hline Grade 10 & 0.069 & 0.254 & 0.068 & 0.252 \\
\hline Grade 11 & 0.063 & 0.244 & 0.065 & 0.246 \\
\hline Grade 12 & 0.080 & 0.271 & 0.083 & 0.276 \\
\hline Certificate I-IV ${ }^{a}$ & 0.225 & 0.417 & 0.230 & 0.421 \\
\hline Diploma/Advanced diploma & 0.084 & 0.278 & 0.087 & 0.283 \\
\hline Bachelor's degree or more & 0.151 & 0.358 & 0.158 & 0.365 \\
\hline \multicolumn{5}{|l|}{ Mother's education } \\
\hline Unknown & 0.134 & 0.34 & 0.128 & 0.334 \\
\hline Grade 9 or less & 0.066 & 0.249 & 0.059 & 0.236 \\
\hline Grade 10 & 0.095 & 0.294 & 0.092 & 0.289 \\
\hline Grade 11 & 0.109 & 0.311 & 0.111 & 0.314 \\
\hline Grade 12 & 0.113 & 0.317 & 0.117 & 0.322 \\
\hline Certificate I-IV & 0.203 & 0.402 & 0.204 & 0.403 \\
\hline Diploma/Advanced diploma & 0.114 & 0.318 & 0.117 & 0.321 \\
\hline Bachelor's degree or more & 0.165 & 0.371 & 0.171 & 0.377 \\
\hline Number of observations & \multicolumn{2}{|c|}{66,686} & \multicolumn{2}{|c|}{58,471} \\
\hline
\end{tabular}

Note. ${ }^{\mathrm{a} C e r t i f i c a t e ~ I-I V}$ are equivalent to level $2 \mathrm{C}-4 \mathrm{~B}$ in the International Standard Classification of Education. 
Appendix B. Seventh-grade students not present in the twelfth-grade data

Four categories of students in our seventh-grade cohort who do not appear in the twelfth-grade data, and are therefore counted as not having achieved an ATAR, may have achieved an equivalent qualification elsewhere or at a different time. They include students emigrating from Victoria between the seventh and twelfth grades; students held back a year in that period; students or skipping a year in that period; and students earning the equivalent International Baccalaureate Diploma (IBD).

We estimate the number of students leaving Victoria between the seventh and twelfth grades as follows. There were just over 60,000 annual departures from Victoria in 2009; and in Australia as a whole, just under 4\% of internal migrants were between the ages of 15-19 (Australian Bureau of Statistics, 2009, Migration Australia, cat. no. 3412.0, tables 5.3, 5.8, http://www.abs.gov.au/AUSSTATS/abs@.nsf/DetailsPage/3412.02009-10?OpenDocument).

Assuming this age distribution of internal migrants applies also to Victoria and distributes evenly between the ages of 15 and 19, there were 480 departures per cohort each year. This amounts to 2,640 departures in the 5.5 years between the seventh grade NAPLAN tests in May 2008 and the twelfth grade VCE exams in November 2012, equal to about 4.5\% of our seventhgrade cohort of 58,471 students. If their success rates in achieving a VCE are similar to the $70 \%$ national rate, this amounts to $3.2 \%$ of the study cohort achieving a VCE or equivalent but uncounted as such. Thus this category alone accounts for the large part of the shortfall in VCE completions. It seems reasonable to assume that these uncounted students are distributed randomly across STEM subjects and gender, and so their omission should not bias our estimates of gendered patterns of choice in STEM.

NAPLAN data indicates that $0.85 \%$ of students in Victoria government schools repeat grade nine annually (Table B). Assuming a similar share in earlier years and a much smaller share, say half that, in later years yields an overall attrition rate of 3.4\% between grades seven and twelve in government schools. Repetition rates are presumably substantially lower in feepaying non-government schools, say half that, $1.7 \%$, or about $2.6 \%$ overall. This category is probably not gender neutral, as male attrition rates are higher. However, the share of students in this group sitting for a VCE and choosing mathematically intensive subjects is not likely to be high, and therefore counting them as not having chosen these subjects should not substantially bias our estimates of large gender differences in subject choice. 
Table B. Students repeating Grade 9 in Victoria government schools

\begin{tabular}{cccc}
\hline Year & Number of students in cohort & Students repeating Grade 9 & Share \\
\hline 2009 & 40,794 & 335 & $0.82 \%$ \\
2010 & 39,962 & 309 & $0.77 \%$ \\
2011 & 39,848 & 373 & $0.94 \%$ \\
2012 & 39,486 & 344 & $0.87 \%$ \\
\hline total & 160,090 & 1,361 & $0.85 \%$ \\
\hline
\end{tabular}

Source: Victoria DET NAPLAN data, authors' tabulation

We do not have data on the share of students skipping a grade between grades seven and twelve, but their share in the population at these ages is likely to be smaller than the share of repeaters, perhaps $1-2 \%$ of the cohort. Many of these are likely to choose mathematically intensive VCE subjects, but the lack of an obvious gender bias suggests that their impact on our results is limited.

Each year around 500 students in Victoria sit for the International Baccalaureate Diploma (IBD), an alternative system of high school matriculation equivalent to a VCE (about $0.8 \%$ of the cohort). They have a much higher success rate, but aggregate data indicates that they split equally between male and female students, and so should have little if any effect on our results.

In sum, we lose about $4.5 \%$ of the cohort to migration, $2.6 \%$ to repetition, less than that to students skipping a grade, and $0.8 \%$ to the IBD. Of all these, only repeaters have a clear gender bias, but their rate of VCE completion is probably well under average, and the share of repeaters choosing mathematically intensive VCE subjects is likely to be small. This leads us to conclude that these missing observations are not likely to substantially change the patterns we observe. 
Appendix C. Coefficient estimates from OLS regressions

Table C. Coefficients from OLS regressions

\begin{tabular}{|c|c|c|c|c|c|c|}
\hline & Physics & IT & $\begin{array}{l}\text { Specialist } \\
\text { math }\end{array}$ & $\begin{array}{l}\text { Math } \\
\text { methods }\end{array}$ & Chemistry & $\begin{array}{l}\text { Life } \\
\text { sciences }\end{array}$ \\
\hline Female & $\begin{array}{l}-0.091^{* * *} \\
(0.003)\end{array}$ & $\begin{array}{l}-0.083^{* * *} \\
(0.004)\end{array}$ & $\begin{array}{l}-0.013 * * * \\
(0.002)\end{array}$ & $\begin{array}{l}-0.009 * * * \\
(0.003)\end{array}$ & $\begin{array}{l}0.018^{* * *} \\
(0.003)\end{array}$ & $\begin{array}{l}0.103^{* * *} \\
(0.004)\end{array}$ \\
\hline Numeracy & $0.029 * * *$ & 0.001 & $0.025 * * *$ & $0.038 * * *$ & $0.035^{* * *}$ & $-0.006 *$ \\
\hline Grade 7 & $(0.003)$ & $(0.002)$ & $(0.002)$ & $(0.004)$ & $(0.003)$ & $(0.003)$ \\
\hline Reading & -0.003 & $0.005^{* * *}$ & $-0.008 * * *$ & -0.004 & -0.003 & $0.019 * * *$ \\
\hline Grade 7 & $(0.002)$ & $(0.002)$ & $(0.002)$ & $(0.003)$ & $(0.003)$ & $(0.003)$ \\
\hline Numeracy & $0.065^{* * *}$ & $0.006^{* * *}$ & $0.064 * * *$ & $0.096 * * *$ & $0.093 * * *$ & $0.050 * * *$ \\
\hline Grade 9 & $(0.003)$ & $(0.002)$ & $(0.003)$ & $(0.004)$ & $(0.004)$ & $(0.003)$ \\
\hline Reading & 0.001 & $0.006^{* * *}$ & $-0.010 * * *$ & $0.016^{* * *}$ & $0.007^{* * *}$ & $0.033^{* * *}$ \\
\hline Grade 9 & $(0.002)$ & $(0.002)$ & $(0.002)$ & $(0.002)$ & $(0.002)$ & $(0.003)$ \\
\hline SES cat. 2 & $\begin{array}{l}-0.002 \\
(0.003)\end{array}$ & $\begin{array}{l}0.006^{* *} \\
(0.003)\end{array}$ & $\begin{array}{l}-0.003^{*} \\
(0.002)\end{array}$ & $\begin{array}{l}-0.007^{* *} \\
(0.004)\end{array}$ & $\begin{array}{l}-0.010^{* * *} \\
(0.003)\end{array}$ & $\begin{array}{l}0.019 * * * \\
(0.004)\end{array}$ \\
\hline SES cat. 3 & $\begin{array}{l}0.005 \\
(0.003)\end{array}$ & $\begin{array}{l}0.006^{*} \\
(0.003)\end{array}$ & $\begin{array}{l}-0.004^{*} \\
(0.002)\end{array}$ & $\begin{array}{l}0.009 * * \\
(0.004)\end{array}$ & $\begin{array}{l}0.006 \\
(0.004)\end{array}$ & $\begin{array}{l}0.036 * * * \\
(0.005)\end{array}$ \\
\hline SES cat. 4 & $\begin{array}{l}0.023 * * * \\
(0.004)\end{array}$ & $\begin{array}{l}0.001 \\
(0.003)\end{array}$ & $\begin{array}{l}0.005 \\
(0.003)\end{array}$ & $\begin{array}{l}0.039 * * * \\
(0.005)\end{array}$ & $\begin{array}{l}0.031^{* * *} \\
(0.005)\end{array}$ & $\begin{array}{l}0.061^{* * *} \\
(0.005)\end{array}$ \\
\hline LBOTE & $\begin{array}{l}0.044 * * * \\
(0.004)\end{array}$ & $\begin{array}{l}0.020 * * * \\
(0.003)\end{array}$ & $\begin{array}{l}0.046 * * * \\
(0.003)\end{array}$ & $\begin{array}{l}0.104^{* * *} \\
(0.006)\end{array}$ & $\begin{array}{l}0.106 * * * \\
(0.006)\end{array}$ & $\begin{array}{l}0.052^{* * *} \\
(0.005)\end{array}$ \\
\hline Gov. school & $\begin{array}{l}-0.004 \\
(0.004)\end{array}$ & $\begin{array}{l}-0.021^{* * *} \\
(0.005)\end{array}$ & $\begin{array}{l}0.008^{* *} \\
(0.004)\end{array}$ & $\begin{array}{l}-0.016^{* *} \\
(0.006)\end{array}$ & $\begin{array}{l}-0.007 \\
(0.007)\end{array}$ & $\begin{array}{l}-0.010 \\
(0.007)\end{array}$ \\
\hline $\begin{array}{l}\text { Median numeracy } \\
\text { score Grade } 7\end{array}$ & $\begin{array}{l}-0.066^{* * *} \\
(0.017)\end{array}$ & $\begin{array}{l}-0.072^{* * *} \\
(0.018)\end{array}$ & $\begin{array}{l}-0.003 \\
(0.012)\end{array}$ & $\begin{array}{l}0.079 * * * \\
(0.022)\end{array}$ & $\begin{array}{l}0.056^{* *} \\
(0.023)\end{array}$ & $\begin{array}{l}-0.067^{* *} \\
(0.027)\end{array}$ \\
\hline $\begin{array}{l}\text { Median male } \\
\text { numeracy Grade } 7\end{array}$ & $\begin{array}{l}0.038 * * * \\
(0.008)\end{array}$ & $\begin{array}{l}0.031 * * * \\
(0.009)\end{array}$ & $\begin{array}{l}0.000 \\
(0.008)\end{array}$ & $\begin{array}{l}-0.030 * * \\
(0.014)\end{array}$ & $\begin{array}{l}-0.046^{* * *} \\
(0.014)\end{array}$ & $\begin{array}{l}0.032^{* *} \\
(0.016)\end{array}$ \\
\hline $\begin{array}{l}\text { Median female } \\
\text { numeracy Grade } 7\end{array}$ & $\begin{array}{l}0.008 \\
(0.013)\end{array}$ & $\begin{array}{l}0.030 * * \\
(0.014)\end{array}$ & $\begin{array}{l}-0.013^{*} \\
(0.008)\end{array}$ & $\begin{array}{l}-0.041 * * * \\
(0.015)\end{array}$ & $\begin{array}{l}-0.025 \\
(0.016)\end{array}$ & $\begin{array}{l}0.048 * * \\
(0.019)\end{array}$ \\
\hline Median SES & $\begin{array}{l}-0.004 \\
(0.003)\end{array}$ & $\begin{array}{l}-0.003 \\
(0.004)\end{array}$ & $\begin{array}{l}0.007^{* *} \\
(0.003)\end{array}$ & $\begin{array}{l}-0.007 \\
(0.005)\end{array}$ & $\begin{array}{l}0.004 \\
(0.005)\end{array}$ & $\begin{array}{l}-0.008 \\
(0.006)\end{array}$ \\
\hline Share of girls & $\begin{array}{l}-0.007 \\
(0.010)\end{array}$ & $\begin{array}{l}-0.018^{* *} \\
(0.009)\end{array}$ & $\begin{array}{l}-0.004 \\
(0.007)\end{array}$ & $\begin{array}{l}0.037^{* *} \\
(0.014)\end{array}$ & $\begin{array}{l}0.044^{* * *} \\
(0.013)\end{array}$ & $\begin{array}{l}-0.016 \\
(0.015)\end{array}$ \\
\hline Const. & $\begin{array}{l}0.128 * * * \\
(0.012)\end{array}$ & $\begin{array}{l}0.114 * * * \\
(0.011)\end{array}$ & $\begin{array}{l}0.019 * * \\
(0.009)\end{array}$ & $\begin{array}{l}0.137^{* * *} \\
(0.017)\end{array}$ & $\begin{array}{l}0.059 * * * \\
(0.016)\end{array}$ & $\begin{array}{l}0.120 * * * \\
(0.020)\end{array}$ \\
\hline$R^{2}$ & 0.149 & 0.043 & 0.150 & 0.189 & 0.189 & 0.086 \\
\hline
\end{tabular}

Notes: Coefficients from OLS regressions. Number of observations 58,471. Standard errors in parentheses, clustered by seventh-grade school level. Significance levels: ${ }^{*} p<0.1,{ }^{* *} p<0.05,{ }^{* * *} p<0.01$ 
Appendix D. Coefficient estimates from OLS regressions limited to students with all four grades (no imputed scores)

Table D. Coefficients from OLS regressions limited to students with all four grades (no imputed scores)

\begin{tabular}{|c|c|c|c|c|c|c|}
\hline & Physics & IT & $\begin{array}{l}\text { Specialist } \\
\text { math }\end{array}$ & $\begin{array}{l}\text { Math } \\
\text { methods }\end{array}$ & Chemistry & $\begin{array}{l}\text { Life } \\
\text { sciences }\end{array}$ \\
\hline \multirow[t]{2}{*}{ Female } & $-0.096 * * *$ & $-0.088 * * *$ & $-0.011 * * *$ & $-0.008^{*}$ & $0.023^{* * *}$ & $0.112^{* * *}$ \\
\hline & $(0.004)$ & $(0.004)$ & $(0.002)$ & $(0.004)$ & $(0.003)$ & $(0.004)$ \\
\hline Numeracy & $0.031 * * *$ & 0.001 & $0.027 * * *$ & $0.041 * * *$ & $0.038 * * *$ & $-0.007 * *$ \\
\hline Grade 7 & $(0.003)$ & $(0.002)$ & $(0.002)$ & $(0.004)$ & $(0.003)$ & $(0.004)$ \\
\hline Reading & -0.002 & $0.005^{* * *}$ & $-0.008 * * *$ & -0.003 & -0.001 & $0.023^{* * *}$ \\
\hline Grade 7 & $(0.002)$ & $(0.002)$ & $(0.002)$ & $(0.003)$ & $(0.003)$ & $(0.003)$ \\
\hline Numeracy & $0.068 * * *$ & $0.005^{* *}$ & $0.067 * * *$ & $0.099 * * *$ & $0.097^{* * *}$ & $0.049 * * *$ \\
\hline Grade 9 & $(0.003)$ & $(0.002)$ & $(0.003)$ & $(0.004)$ & $(0.004)$ & $(0.004)$ \\
\hline Reading & -0.001 & $0.006 * * *$ & $-0.012 * * *$ & $0.016^{* * *}$ & $0.006^{* *}$ & $0.035 * * *$ \\
\hline Grade 9 & $(0.002)$ & $(0.002)$ & $(0.002)$ & $(0.003)$ & $(0.003)$ & $(0.003)$ \\
\hline \multirow[t]{2}{*}{ SES cat. 2} & -0.003 & 0.004 & -0.003 & -0.005 & $-0.008 * *$ & $0.019 * * *$ \\
\hline & $(0.003)$ & $(0.003)$ & $(0.002)$ & $(0.004)$ & $(0.004)$ & $(0.005)$ \\
\hline \multirow[t]{2}{*}{ SES cat. 3} & 0.004 & 0.005 & -0.004 & $0.010 * *$ & $0.008^{*}$ & $0.038 * * *$ \\
\hline & $(0.004)$ & $(0.003)$ & $(0.003)$ & $(0.005)$ & $(0.004)$ & $(0.006)$ \\
\hline \multirow[t]{2}{*}{ SES cat. 4} & $0.021 * * *$ & -0.001 & 0.005 & $0.039 * * *$ & $0.032 * * *$ & $0.060 * * *$ \\
\hline & $(0.004)$ & $(0.004)$ & $(0.003)$ & $(0.005)$ & $(0.005)$ & $(0.006)$ \\
\hline \multirow[t]{2}{*}{ LBOTE } & $0.046 * * *$ & $0.017 * * *$ & $0.051 * * *$ & $0.111^{* * *}$ & $0.116^{* * *}$ & $0.054^{* * *}$ \\
\hline & $(0.004)$ & $(0.004)$ & $(0.004)$ & $(0.006)$ & $(0.006)$ & $(0.006)$ \\
\hline \multirow[t]{2}{*}{ Gov. school } & -0.002 & $-0.018 * * *$ & $0.009 * *$ & $-0.013^{* *}$ & -0.006 & -0.009 \\
\hline & $(0.004)$ & $(0.005)$ & $(0.004)$ & $(0.007)$ & $(0.007)$ & $(0.007)$ \\
\hline \multirow{2}{*}{$\begin{array}{l}\text { Median numeracy } \\
\text { score Grade } 7\end{array}$} & $-0.065 * * *$ & $-0.081 * * *$ & -0.011 & $0.066 * * *$ & 0.040 & $-0.071 * *$ \\
\hline & $(0.018)$ & $(0.019)$ & $(0.013)$ & $(0.024)$ & $(0.025)$ & $(0.028)$ \\
\hline \multirow{2}{*}{$\begin{array}{l}\text { Median male } \\
\text { numeracy Grade } 7\end{array}$} & $0.037 * * *$ & $0.032 * * *$ & 0.002 & -0.022 & $-0.034 * *$ & $0.036^{* *}$ \\
\hline & (0.009) & (0.009) & $(0.008)$ & $(0.015)$ & $(0.015)$ & $(0.016)$ \\
\hline \multirow{2}{*}{$\begin{array}{l}\text { Median female } \\
\text { numeracy Grade } 7\end{array}$} & 0.006 & $0.034^{* *}$ & -0.011 & $-0.034^{* *}$ & -0.019 & $0.048 * *$ \\
\hline & $(0.014)$ & $(0.015)$ & $(0.008)$ & $(0.016)$ & $(0.018)$ & $(0.020)$ \\
\hline \multirow[t]{2}{*}{ Median SES } & -0.004 & -0.001 & $0.008 * * *$ & -0.007 & 0.003 & -0.010 \\
\hline & $(0.004)$ & $(0.004)$ & $(0.003)$ & $(0.006)$ & $(0.005)$ & $(0.006)$ \\
\hline \multirow[t]{2}{*}{ Share of girls } & -0.003 & -0.015 & -0.005 & $0.036 * *$ & $0.042^{* * *}$ & -0.021 \\
\hline & $(0.011)$ & $(0.010)$ & $(0.008)$ & $(0.016)$ & $(0.015)$ & $(0.016)$ \\
\hline \multirow[t]{2}{*}{ Const. } & $0.128 * * *$ & $0.114 * * *$ & 0.012 & $0.136^{* * *}$ & $0.058^{* * *}$ & $0.124^{* * *}$ \\
\hline & $(0.013)$ & $(0.012)$ & $(0.010)$ & $(0.018)$ & $(0.017)$ & $(0.021)$ \\
\hline$R^{2}$ & 0.153 & 0.044 & 0.156 & 0.189 & 0.192 & 0.086 \\
\hline
\end{tabular}

Notes: Coefficients from OLS regressions. Number of observations 48,078. Standard errors in parentheses, clustered by seventh-grade school level. Significance levels: ${ }^{*} p<0.1,{ }^{* *} p<0.05,{ }^{* * *} p<0.01$ 
Appendix E. Coefficient estimates from the OLS regressions by gender Table E. Coefficients from OLS regressions by gender

\begin{tabular}{|c|c|c|c|c|c|c|c|c|c|c|c|c|}
\hline & \multicolumn{2}{|c|}{ Physics } & \multicolumn{2}{|c|}{ IT } & \multicolumn{2}{|c|}{ Specialist math } & \multicolumn{2}{|c|}{ Math methods } & \multicolumn{2}{|c|}{ Chemistry } & \multicolumn{2}{|c|}{ Life science } \\
\hline & Female & Male & Female & Male & Female & Male & Female & Male & Female & Male & Female & Male \\
\hline Numeracy & $0.015 * * *$ & $0.041^{* * *}$ & -0.001 & 0.001 & $0.021 * * *$ & $0.028 * * *$ & $0.043 * * *$ & $0.033 * * *$ & $0.039 * * *$ & $0.032 * * *$ & -0.006 & -0.006 \\
\hline Grade 7 & $(0.002)$ & (0.004) & $(0.001)$ & $(0.004)$ & $(0.003)$ & $(0.003)$ & (0.005) & $(0.005)$ & $(0.005)$ & $(0.004)$ & $(0.006)$ & (0.004) \\
\hline Reading & 0.001 & -0.004 & $-0.002 * *$ & $0.011 * * *$ & $-0.008 * * *$ & $-0.007 * * *$ & $-0.007^{*}$ & -0.001 & $-0.010 * * *$ & 0.004 & $0.014 * * *$ & $0.023 * * *$ \\
\hline Grade 7 & $(0.002)$ & $(0.004)$ & $(0.001)$ & $(0.003)$ & $(0.002)$ & $(0.003)$ & $(0.004)$ & $(0.004)$ & $(0.003)$ & $(0.004)$ & $(0.004)$ & $(0.003)$ \\
\hline Numeracy & $0.029 * * *$ & $0.090 * * *$ & $0.002^{*}$ & $0.008 * *$ & $0.040 * * *$ & $0.080 * * *$ & $0.103 * * *$ & $0.090 * * *$ & $0.097 * * *$ & $0.091 * * *$ & $0.077 * * *$ & $0.031 * * *$ \\
\hline Grade 9 & $(0.003)$ & $(0.004)$ & $(0.001)$ & $(0.004)$ & $(0.003)$ & $(0.004)$ & $(0.005)$ & $(0.005)$ & $(0.005)$ & $(0.005)$ & $(0.005)$ & $(0.004)$ \\
\hline Reading & $-0.005^{* * *}$ & $0.009 * *$ & 0.001 & $0.011 * * *$ & $-0.009 * * *$ & $-0.011 * * *$ & $0.011^{* * *}$ & $0.020 * * *$ & $0.007^{*}$ & $0.006 * *$ & $0.040 * * *$ & $0.026 * * *$ \\
\hline Grade 9 & $(0.002)$ & $(0.004)$ & $(0.001)$ & $(0.003)$ & $(0.002)$ & $(0.003)$ & $(0.004)$ & $(0.003)$ & $(0.004)$ & $(0.003)$ & $(0.004)$ & $(0.003)$ \\
\hline \multirow[t]{2}{*}{ SES cat. 2} & -0.000 & -0.004 & 0.001 & $0.011 * *$ & -0.001 & $-0.005^{*}$ & $-0.009 *$ & -0.005 & $-0.009 * *$ & $-0.009 * *$ & $0.027 * * *$ & $0.010 * *$ \\
\hline & $(0.002)$ & $(0.005)$ & $(0.002)$ & $(0.005)$ & $(0.002)$ & $(0.003)$ & $(0.004)$ & $(0.005)$ & $(0.004)$ & $(0.004)$ & $(0.007)$ & $(0.005)$ \\
\hline \multirow[t]{2}{*}{ SES cat. 3} & 0.001 & $0.010^{*}$ & 0.001 & $0.011^{*}$ & -0.001 & $-0.007^{*}$ & 0.000 & $0.019 * * *$ & 0.005 & 0.008 & $0.045^{* * *}$ & $0.026 * * *$ \\
\hline & $(0.003)$ & $(0.005)$ & $(0.002)$ & $(0.006)$ & $(0.002)$ & $(0.004)$ & $(0.005)$ & $(0.006)$ & $(0.005)$ & $(0.005)$ & $(0.007)$ & $(0.006)$ \\
\hline \multirow[t]{2}{*}{ SES cat. 4} & 0.003 & $0.043 * * *$ & 0.002 & 0.000 & -0.003 & $0.011 * *$ & $0.021 * * *$ & $0.057 * * *$ & $0.021 * * *$ & $0.040 * * *$ & $0.074 * * *$ & $0.047^{* * *}$ \\
\hline & $(0.003)$ & $(0.007)$ & $(0.002)$ & $(0.006)$ & $(0.003)$ & $(0.005)$ & $(0.007)$ & $(0.007)$ & $(0.006)$ & $(0.006)$ & $(0.008)$ & $(0.006)$ \\
\hline \multirow[t]{2}{*}{ LBOTE } & $0.019 * * *$ & $0.072 * * *$ & $0.008 * * *$ & $0.033 * * *$ & $0.037 * * *$ & $0.056 * * *$ & $0.116 * * *$ & $0.090 * * *$ & $0.118 * * *$ & $0.092 * * *$ & $0.064 * * *$ & $0.040 * * *$ \\
\hline & $(0.003)$ & $(0.006)$ & $(0.002)$ & $(0.006)$ & $(0.003)$ & $(0.005)$ & $(0.007)$ & $(0.007)$ & $(0.007)$ & $(0.007)$ & $(0.008)$ & $(0.006)$ \\
\hline \multirow[t]{2}{*}{ Gov. school } & 0.000 & -0.009 & $-0.006 * *$ & $-0.039 * * *$ & $0.006^{* *}$ & $0.011^{* *}$ & -0.004 & $-0.019 * *$ & -0.008 & -0.000 & -0.018 & -0.006 \\
\hline & $(0.003)$ & $(0.007)$ & $(0.003)$ & $(0.009)$ & $(0.003)$ & $(0.005)$ & $(0.007)$ & $(0.008)$ & $(0.008)$ & $(0.008)$ & $(0.011)$ & $(0.007)$ \\
\hline Median num. & -0.002 & $-0.100 * * *$ & $-0.029 * *$ & $-0.129 * * *$ & 0.015 & 0.008 & $0.083^{* *}$ & 0.038 & 0.051 & 0.032 & $-0.133^{* * *}$ & -0.031 \\
\hline score Grade 7 & $(0.015)$ & $(0.031)$ & $(0.012)$ & $(0.034)$ & $(0.016)$ & $(0.018)$ & $(0.035)$ & $(0.032)$ & $(0.033)$ & $(0.034)$ & $(0.047)$ & $(0.033)$ \\
\hline Median male & -0.001 & 0.031 & $0.010 * *$ & $0.070 * * *$ & -0.013 & $-0.026 * *$ & -0.025 & -0.003 & $-0.043 * * *$ & -0.031 & $0.049 * *$ & 0.030 \\
\hline Num. Grade 7 & $(0.007)$ & $(0.021)$ & $(0.004)$ & $(0.025)$ & (0.009) & $(0.013)$ & $(0.017)$ & $(0.020)$ & $(0.016)$ & $(0.022)$ & $(0.022)$ & $(0.022)$ \\
\hline Median female & -0.011 & $0.043 * * *$ & $0.018^{*}$ & $0.037^{* *}$ & -0.016 & 0.001 & $-0.044 *$ & $-0.034^{*}$ & -0.022 & -0.018 & $0.090 * *$ & 0.021 \\
\hline num. Grade 7 & $(0.011)$ & $(0.017)$ & $(0.010)$ & $(0.018)$ & $(0.010)$ & $(0.010)$ & $(0.025)$ & $(0.018)$ & $(0.024)$ & $(0.020)$ & $(0.035)$ & $(0.020)$ \\
\hline \multirow[t]{2}{*}{ Median SES } & -0.002 & -0.005 & -0.001 & -0.005 & $0.006^{* *}$ & $0.010^{* *}$ & $-0.012 *$ & -0.003 & 0.001 & 0.006 & -0.011 & -0.004 \\
\hline & $(0.002)$ & $(0.006)$ & $(0.002)$ & $(0.007)$ & $(0.003)$ & $(0.004)$ & $(0.006)$ & $(0.007)$ & $(0.006)$ & $(0.006)$ & (0.009) & $(0.006)$ \\
\hline \multirow[t]{2}{*}{ Share of girls } & $0.031 * * *$ & 0.025 & -0.011 & -0.007 & $0.013^{*}$ & 0.020 & $0.078 * * *$ & 0.002 & $0.063 * * *$ & 0.011 & $-0.055^{* *}$ & -0.010 \\
\hline & $(0.008)$ & $(0.024)$ & $(0.008)$ & $(0.023)$ & $(0.008)$ & $(0.015)$ & $(0.019)$ & $(0.027)$ & $(0.017)$ & $(0.026)$ & $(0.026)$ & $(0.024)$ \\
\hline \multirow[t]{2}{*}{ Const. } & 0.013 & $0.111^{* * *}$ & $0.021 * * *$ & $0.116 * * *$ & 0.001 & 0.003 & $0.117^{* * *}$ & $0.139 * * *$ & $0.075 * * *$ & $0.064 * * *$ & $0.253 * * *$ & $0.113^{* * *}$ \\
\hline & $(0.009)$ & $(0.020)$ & $(0.007)$ & $(0.019)$ & $(0.009)$ & $(0.014)$ & $(0.021)$ & $(0.023)$ & $(0.019)$ & $(0.023)$ & $(0.031)$ & $(0.023)$ \\
\hline$R^{2}$ & 0.052 & 0.160 & 0.003 & 0.015 & 0.101 & 0.177 & 0.200 & 0.179 & 0.186 & 0.193 & 0.083 & 0.062 \\
\hline
\end{tabular}

Notes: Coefficients from OLS regressions. Number of female students 29,244, number of male students, 29,227. Standard errors in parentheses, clustered by seventhgrade school level. Significance levels: ${ }^{*} p<0.1,{ }^{* *} p<0.05,{ }^{* *} p<0.01$ 
Appendix F. Coefficient estimates from the OLS regressions by school type, gender and school fixed effects

Table F1. Coefficients from OLS regression by school type, gender and school fixed effects

\begin{tabular}{|c|c|c|c|c|c|c|c|c|}
\hline & \multicolumn{4}{|c|}{ Physics } & \multicolumn{4}{|c|}{ Information technology } \\
\hline & $\begin{array}{l}\text { Single-sex } \\
\text { female }\end{array}$ & $\begin{array}{l}\text { Co-Ed } \\
\text { female }\end{array}$ & $\begin{array}{l}\text { Co-Ed } \\
\text { male }\end{array}$ & $\begin{array}{l}\text { Single-sex } \\
\text { male }\end{array}$ & $\begin{array}{l}\text { Single-sex } \\
\text { female }\end{array}$ & $\begin{array}{l}\text { Co-Ed } \\
\text { female }\end{array}$ & $\begin{array}{l}\text { Co-Ed } \\
\text { male }\end{array}$ & $\begin{array}{l}\text { Single- } \\
\text { sex male }\end{array}$ \\
\hline Numeracy & $0.020 * * *$ & $0.012 * * *$ & $0.037^{* * *}$ & $0.049 * * *$ & $-0.005^{* *}$ & 0.000 & -0.001 & 0.002 \\
\hline Grade 7 & $(0.005)$ & $(0.003)$ & $(0.005)$ & $(0.010)$ & $(0.002)$ & $(0.002)$ & $(0.004)$ & $(0.009)$ \\
\hline Reading & 0.001 & 0.000 & -0.004 & -0.002 & $-0.003^{*}$ & -0.002 & $0.012 * * *$ & 0.008 \\
\hline Grade 7 & $(0.005)$ & $(0.002)$ & $(0.004)$ & $(0.012)$ & $(0.002)$ & $(0.001)$ & $(0.004)$ & $(0.008)$ \\
\hline Numeracy & $0.052 * * *$ & $0.022 * * *$ & $0.091 * * *$ & $0.092 * * *$ & $0.006 * * *$ & 0.001 & $0.013^{* * *}$ & -0.007 \\
\hline Grade 9 & $(0.006)$ & $(0.003)$ & $(0.005)$ & $(0.012)$ & $(0.002)$ & $(0.001)$ & $(0.004)$ & $(0.007)$ \\
\hline Reading & $-0.012 * *$ & -0.002 & $0.011 * * *$ & -0.003 & -0.001 & 0.002 & $0.011 * * *$ & 0.005 \\
\hline Grade 9 & $(0.005)$ & $(0.002)$ & $(0.004)$ & $(0.011)$ & $(0.002)$ & $(0.001)$ & $(0.004)$ & $(0.009)$ \\
\hline \multirow[t]{2}{*}{ SES cat. 2} & 0.005 & 0.002 & -0.004 & -0.020 & 0.002 & 0.002 & 0.008 & 0.009 \\
\hline & $(0.008)$ & $(0.002)$ & $(0.005)$ & $(0.020)$ & $(0.007)$ & $(0.002)$ & $(0.005)$ & (0.019) \\
\hline \multirow[t]{2}{*}{ SES cat. 3} & 0.007 & -0.000 & $0.010^{*}$ & 0.020 & 0.005 & 0.000 & $0.010^{*}$ & 0.013 \\
\hline & $(0.007)$ & $(0.003)$ & $(0.006)$ & $(0.020)$ & $(0.007)$ & $(0.002)$ & $(0.006)$ & $(0.017)$ \\
\hline \multirow[t]{2}{*}{ SES cat. 4} & $0.013^{*}$ & 0.005 & $0.047^{* * *}$ & 0.027 & 0.000 & 0.003 & -0.002 & -0.002 \\
\hline & $(0.007)$ & $(0.003)$ & $(0.007)$ & $(0.021)$ & $(0.006)$ & $(0.003)$ & $(0.006)$ & (0.017) \\
\hline \multirow[t]{2}{*}{ LBOTE } & $0.016^{*}$ & $0.017^{* * *}$ & $0.078 * * *$ & $0.055^{* * *}$ & 0.003 & $0.006 * *$ & $0.026 * * *$ & 0.003 \\
\hline & $(0.008)$ & $(0.003)$ & $(0.007)$ & $(0.013)$ & $(0.004)$ & $(0.002)$ & $(0.006)$ & $(0.007)$ \\
\hline \multirow[t]{2}{*}{ Const. } & $0.093 * * *$ & -0.001 & $0.156^{* * *}$ & $0.248 * * *$ & -0.006 & -0.003 & -0.003 & 0.005 \\
\hline & $(0.012)$ & $(0.002)$ & $(0.003)$ & $(0.030)$ & $(0.005)$ & $(0.002)$ & $(0.003)$ & $(0.020)$ \\
\hline$R^{2}$ & 0.085 & 0.065 & 0.193 & 0.148 & 0.034 & 0.052 & 0.072 & 0.028 \\
\hline
\end{tabular}

Notes: Coefficients from OLS regressions. Number of observations in single-sex female schools, 6,745; in co-educational female schools, 22,499; in co-educational male schools, 24,599; in single-sex male schools, 4,628. Standard errors in parentheses, clustered by seventh-grade school level. All regressions include school fixed effects. Significance levels: ${ }^{*} p<0.1,{ }^{* *} p<0.05,{ }^{* * *} p<0.01$ 
Table F2. Coefficients from OLS regression by school type, gender and school fixed effects

\begin{tabular}{|c|c|c|c|c|c|c|c|c|}
\hline & \multicolumn{4}{|c|}{ Specialist mathematics } & \multicolumn{4}{|c|}{ Mathematical methods } \\
\hline & $\begin{array}{c}\text { Single-sex } \\
\text { female }\end{array}$ & $\begin{array}{c}\text { Co-Ed } \\
\text { female }\end{array}$ & $\begin{array}{l}\text { Co-Ed } \\
\text { male }\end{array}$ & $\begin{array}{c}\text { Single-sex } \\
\text { male }\end{array}$ & $\begin{array}{c}\text { Single-sex } \\
\text { female }\end{array}$ & $\begin{array}{l}\text { Co-Ed } \\
\text { female }\end{array}$ & $\begin{array}{l}\text { Co-Ed } \\
\text { male }\end{array}$ & $\begin{array}{c}\text { Single-sex } \\
\text { male }\end{array}$ \\
\hline Numeracy & $0.030 * * *$ & $0.015^{* * *}$ & $0.022 * * *$ & $0.048 * * *$ & $0.051^{* * *}$ & $0.041^{* * *}$ & $0.031^{* * *}$ & $0.047 * * *$ \\
\hline Grade 7 & $(0.006)$ & $(0.003)$ & $(0.003)$ & $(0.010)$ & $(0.010)$ & $(0.005)$ & $(0.005)$ & $(0.015)$ \\
\hline Reading & $-0.014 * * *$ & $-0.005^{* *}$ & $-0.005^{*}$ & $-0.017^{* *}$ & -0.012 & -0.005 & -0.002 & 0.008 \\
\hline Grade 7 & $(0.004)$ & $(0.002)$ & $(0.003)$ & $(0.008)$ & $(0.009)$ & $(0.004)$ & $(0.004)$ & $(0.013)$ \\
\hline Numeracy & $0.067 * * *$ & $0.032 * * *$ & $0.079 * * *$ & $0.094 * * *$ & $0.116^{* * *}$ & $0.099 * * *$ & $0.089 * * *$ & $0.082 * * *$ \\
\hline Grade 9 & $(0.008)$ & $(0.003)$ & $(0.004)$ & $(0.010)$ & $(0.012)$ & $(0.005)$ & $(0.005)$ & $(0.013)$ \\
\hline Reading & $-0.013 * * *$ & $-0.007 * * *$ & $-0.009 * * *$ & $-0.014 *$ & $0.022 * *$ & 0.006 & $0.020 * * *$ & $0.034 * * *$ \\
\hline Grade 9 & $(0.004)$ & $(0.002)$ & $(0.003)$ & $(0.008)$ & $(0.009)$ & $(0.004)$ & $(0.004)$ & $(0.009)$ \\
\hline \multirow[t]{2}{*}{ SES cat. 2} & $0.027 * * *$ & $-0.003^{*}$ & -0.004 & -0.009 & $-0.028^{*}$ & -0.001 & -0.001 & -0.012 \\
\hline & $(0.006)$ & $(0.002)$ & $(0.003)$ & (0.014) & $(0.015)$ & $(0.005)$ & $(0.005)$ & $(0.021)$ \\
\hline \multirow[t]{2}{*}{ SES cat. 3} & $0.018 * * *$ & 0.000 & -0.005 & -0.005 & -0.005 & -0.002 & $0.019 * * *$ & 0.016 \\
\hline & $(0.007)$ & $(0.002)$ & $(0.004)$ & $(0.011)$ & $(0.015)$ & $(0.005)$ & $(0.006)$ & $(0.020)$ \\
\hline \multirow[t]{2}{*}{ SES cat. 4} & $0.019 * * *$ & -0.003 & $0.017 * * *$ & -0.001 & 0.014 & $0.026 * * *$ & $0.056 * * *$ & $0.070 * * *$ \\
\hline & $(0.007)$ & $(0.003)$ & $(0.005)$ & $(0.013)$ & (0.019) & $(0.007)$ & $(0.007)$ & $(0.024)$ \\
\hline \multirow[t]{2}{*}{ LBOTE } & $0.050 * * *$ & $0.031 * * *$ & $0.055^{* * *}$ & $0.080 * * *$ & $0.102 * * *$ & $0.104^{* * *}$ & $0.089 * * *$ & $0.066 * * *$ \\
\hline & $(0.006)$ & $(0.004)$ & $(0.006)$ & $(0.011)$ & $(0.015)$ & $(0.008)$ & $(0.008)$ & $(0.022)$ \\
\hline \multirow[t]{2}{*}{ Const. } & $0.081 * * *$ & $0.003 * *$ & $-0.010 * * *$ & $0.203 * * *$ & $0.200 * * *$ & $0.100 * * *$ & $0.154^{* * *}$ & $0.326 * * *$ \\
\hline & $(0.011)$ & $(0.002)$ & $(0.002)$ & $(0.025)$ & $(0.018)$ & $(0.004)$ & $(0.004)$ & $(0.030)$ \\
\hline R-sqr & 0.163 & 0.104 & 0.194 & 0.223 & 0.198 & 0.223 & 0.202 & 0.179 \\
\hline
\end{tabular}

Notes: Coefficients from OLS regressions. Number of observations in single-sex female schools, 6,745; in co-educational female schools, 22,499; in co-educational male schools, 24,599; in single-sex male schools, 4,628. Standard errors in parentheses, clustered by seventh-grade school level. All regressions include school fixed effects. Significance levels: ${ }^{*} p<0.1,{ }^{* *} p<0.05,{ }^{* * *} p<0.01$ 
Table F3. Coefficients from OLS regression by school type, gender and school fixed effects

\begin{tabular}{|c|c|c|c|c|c|c|c|c|}
\hline & \multicolumn{4}{|c|}{ Chemistry } & \multicolumn{4}{|c|}{ Life Science } \\
\hline & $\begin{array}{c}\text { Single-sex } \\
\text { female }\end{array}$ & $\begin{array}{l}\text { Co-Ed } \\
\text { female }\end{array}$ & $\begin{array}{l}\text { Co-Ed } \\
\text { male }\end{array}$ & $\begin{array}{c}\text { Single-sex } \\
\text { male }\end{array}$ & $\begin{array}{c}\text { Single-sex } \\
\text { female }\end{array}$ & $\begin{array}{c}\text { Co-Ed } \\
\text { female }\end{array}$ & $\begin{array}{l}\text { Co-Ed } \\
\text { male }\end{array}$ & $\begin{array}{c}\text { Single-sex } \\
\text { male }\end{array}$ \\
\hline Numeracy & $0.060 * * *$ & $0.028 * * *$ & $0.025 * * *$ & $0.058 * * *$ & $-0.021^{*}$ & -0.001 & $-0.008^{*}$ & -0.003 \\
\hline Grade 7 & $(0.011)$ & $(0.005)$ & $(0.005)$ & (0.010) & $(0.011)$ & $(0.006)$ & $(0.004)$ & $(0.010)$ \\
\hline Reading & $-0.018^{* *}$ & -0.006 & 0.005 & 0.004 & 0.011 & $0.017^{* * *}$ & $0.021 * * *$ & $0.028 * * *$ \\
\hline Grade 7 & (0.007) & $(0.004)$ & $(0.004)$ & $(0.008)$ & (0.009) & $(0.005)$ & $(0.004)$ & $(0.010)$ \\
\hline Numeracy & $0.120 * * *$ & $0.089 * * *$ & $0.088 * * *$ & $0.111^{* * *}$ & $0.081^{* * *}$ & $0.076 * * *$ & $0.031^{* * *}$ & $0.035^{* * *}$ \\
\hline Grade 9 & $(0.011)$ & (0.005) & (0.005) & (0.009) & $(0.011)$ & $(0.006)$ & (0.005) & $(0.012)$ \\
\hline Reading & $0.015^{*}$ & 0.006 & $0.009 * *$ & 0.005 & $0.036 * * *$ & $0.040 * * *$ & $0.029 * * *$ & 0.012 \\
\hline Grade 9 & (0.009) & $(0.004)$ & $(0.003)$ & $(0.008)$ & (0.009) & (0.005) & $(0.004)$ & $(0.008)$ \\
\hline \multirow[t]{2}{*}{ SES cat. 2} & -0.013 & -0.003 & -0.005 & $-0.035^{* *}$ & 0.014 & $0.026 * * *$ & $0.009 * *$ & 0.020 \\
\hline & $(0.016)$ & $(0.004)$ & $(0.004)$ & $(0.015)$ & $(0.019)$ & $(0.007)$ & $(0.005)$ & $(0.023)$ \\
\hline \multirow[t]{2}{*}{ SES cat. 3} & -0.004 & 0.007 & 0.009* & -0.006 & 0.034 & $0.038 * * *$ & $0.018^{* * *}$ & 0.039 \\
\hline & $(0.018)$ & $(0.005)$ & $(0.005)$ & (0.019) & $(0.022)$ & $(0.008)$ & $(0.006)$ & $(0.024)$ \\
\hline \multirow[t]{2}{*}{ SES cat. 4} & 0.016 & $0.029 * * *$ & $0.045^{* * *}$ & 0.030 & $0.056 * * *$ & $0.078 * * *$ & $0.049 * * *$ & $0.067^{* * *}$ \\
\hline & (0.018) & (0.007) & $(0.007)$ & $(0.020)$ & (0.019) & (0.009) & (0.007) & (0.019) \\
\hline \multirow[t]{2}{*}{ LBOTE } & $0.122 * * *$ & $0.095 * * *$ & $0.085 * * *$ & $0.113 * * *$ & $0.055^{* * *}$ & $0.062 * * *$ & $0.044^{* * *}$ & $0.030 * *$ \\
\hline & $(0.014)$ & $(0.008)$ & $(0.007)$ & $(0.016)$ & $(0.017)$ & (0.009) & $(0.007)$ & $(0.013)$ \\
\hline \multirow[t]{2}{*}{ Const. } & $0.184^{* * *}$ & $0.096 * * *$ & $0.219 * * *$ & $0.333^{* * *}$ & $0.114^{* * *}$ & $0.107^{* * *}$ & $0.051 * * *$ & $0.103 * * *$ \\
\hline & $(0.019)$ & $(0.004)$ & $(0.003)$ & $(0.032)$ & $(0.018)$ & $(0.006)$ & $(0.003)$ & $(0.032)$ \\
\hline$R^{2}$ & 0.212 & 0.194 & 0.210 & 0.251 & 0.074 & 0.131 & 0.095 & 0.063 \\
\hline
\end{tabular}

Notes: Coefficients from OLS regressions. Number of observations in single-sex female schools, 6,745; in co-educational female schools, 22,499; in co-educational male schools, 24,599; in single-sex male schools, 4,628. Standard errors in parentheses, clustered by seventh-grade school level. All regressions include school fixed effects. Significance levels: ${ }^{*} p<0.1,{ }^{*} p<0.05,{ }^{* * *} p<0.01$ 